\title{
المعجزة القرآنية في فكر الجابري: دراسة تحليلية
}

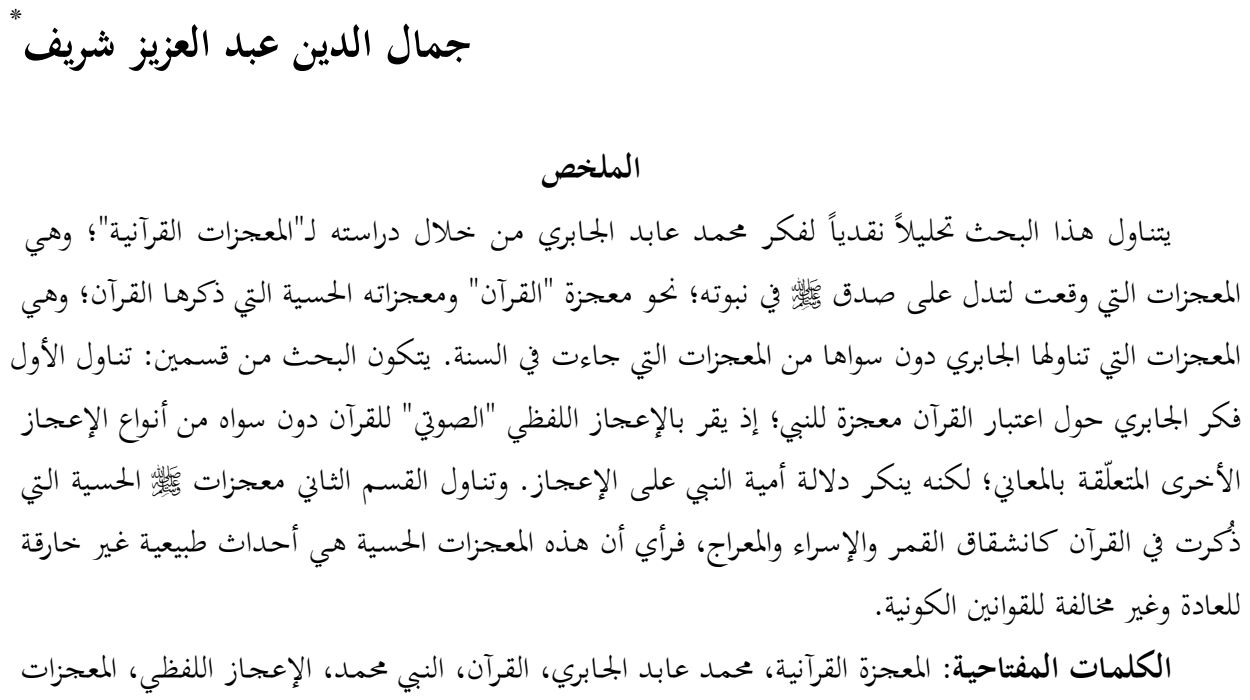

\section{The Qur'anic Miracle in Al-Jabiri's Thought: A Critical Analytical Study}

\section{Abstract}

This paper critically analyzes the thought of Muhammad Abid al-Jabiri in his study of the miracles of Prophet Muhammad (pbuh); i.e, the miracle of Qur'an and sensory miracles mentioned in the Qur'an. The study has two sections: the first deals with the Qur'an as Prophet Muhammad's miracle that validates his Prophethood, which al-Jabiri endorses as 'phonic' or 'verbal' miracle, while disregarding other miracles related to meanings, thereby denying the indication of the Prophet's illiteracy.

The second section discusses sensory miracles that are mentioned in the Qur'an, such as the eclipse of the moon and Al Isra wa Al Mi'raj (The Night Journey and Ascension). Al-Jabiri considers such sensory miracles as ordinary natural events that are not contrary to the cosmic laws.

Keywords: Qur'anic miracle, Muhammad Abid al-Jabiri, Qur'an, Prophet Muhammad, verbal miracle, sensory miracles.

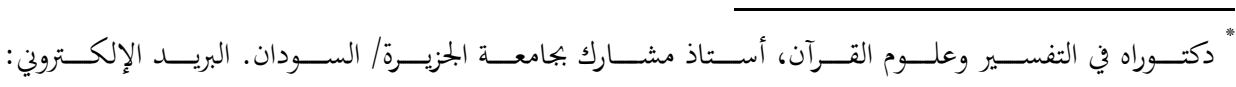

$$
\begin{aligned}
& \text { jamalshari8@gmail.com }
\end{aligned}
$$

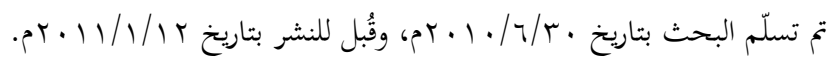




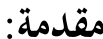

اتخذ أصحاب القراءات الحداثية للقرآن "العقلانية" مرتكزاً من مرتكزاتم التي استندوا إليها، وبناء على ذلك نادوا بضرورة إعادة قراءة التراث الإسلامي ونقده، من خحلال إبراز

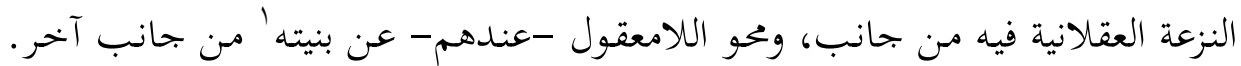

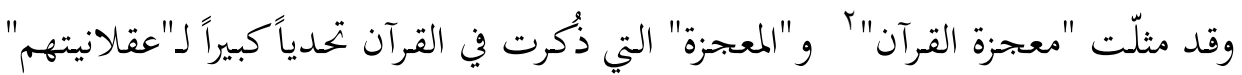
التي تزاورت عن قبول الغيبيات واستنكفت عن الاقتناع بـالخوارق؛ ولهذا كانت المعجزة

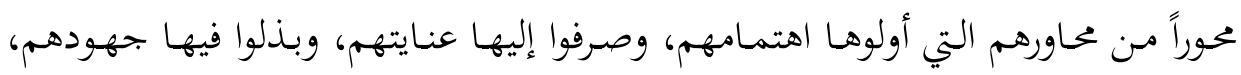
فذهبوا إلى أن هذه المعجزات مـا هي إلا شواهد تاريخية ولم تعد لها الدلالات ذاهـا التي كان يُقال بها في الماضي، وإنما يجب إعادة تفسيرها في ضوء التصورات الحديثة. وفي هذا المضمار ألّف جورج طرابيشي كتابه "المعجزة أو سبات العقل في الإسلام"، وعقد حسن حنفي في كتابه "مـن العقيدة إلى الثورة" فصـالً بعنوان "استحالة المعجزة"، وذهـب حنفي في ذلك إلى أن الماضي إنماكـان زمـن نشر الرسالة والردّ على منكريها، وليس الأمر كذلك الآن، وإنما التحدي في الوقت الحاضر - عنده- هو تحويل الوحي إلى إلى "علم" يقوم على العقل ويستند على الطبيعة، وذهبب إلى أن المعجزات إنما هي قدح في

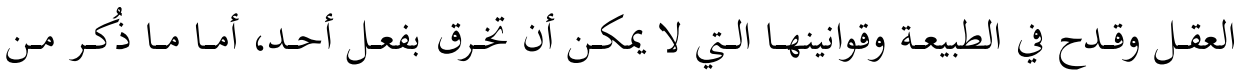

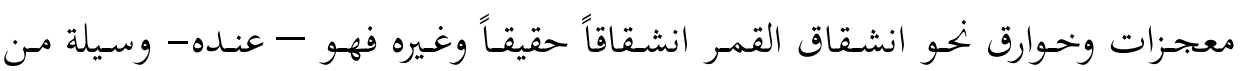

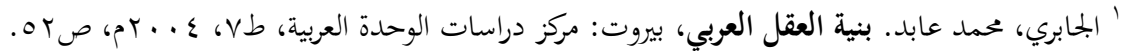

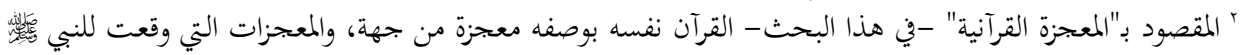

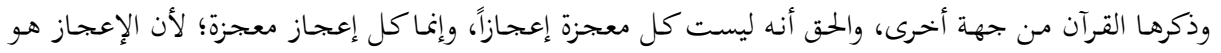

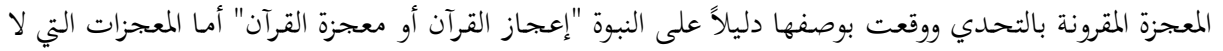

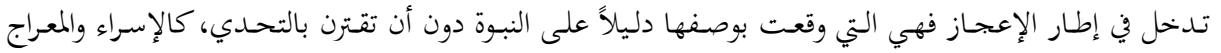

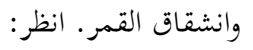

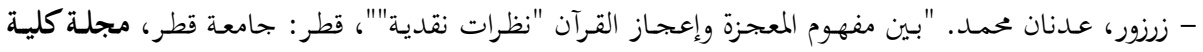

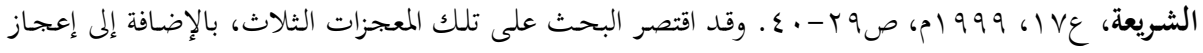


وسائل التخييل، وطريقة من طرق الإقناع في الخيال الشعبي لدى القبائل الصحراوية التي تجهل قوانين العلم وسنن الطبيعة.

وذهـب عبـد البحيد الثـرفي إلى أن هـذه المعجـزات والحـوارق قـد ارتبطت بالأسطورة

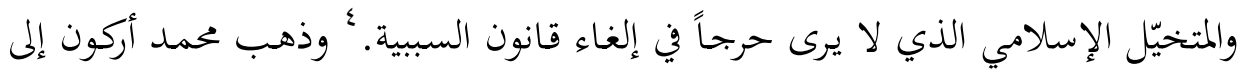
أن هذه المعطيات الخارقة للطبيعة إنما هي تعابير محوَّرة عن مطامح ورؤى حقيقية يمكن

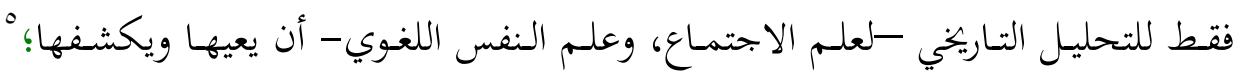
ولأجل هذا ذهب كثير منهم إلى تأويل "المعجزة" تأويلاً بحازياً.

أمـا محمد عابد الجحابري فهو وإن سلك مسلك "العقلنة"، إلا أنه لم ينف المعجزات

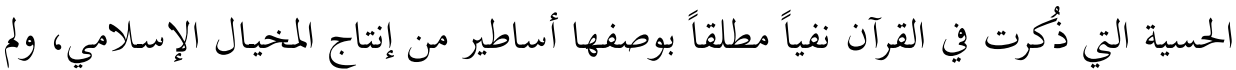

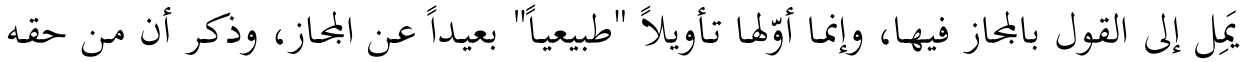
النظر في أقوال العلماء داخل التراث، واختيار ما لا يتعارض مع مبادئ العقل ومعطيات

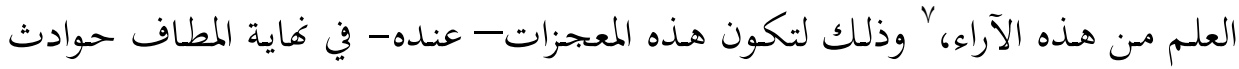
طبيعية غير خارقة للعادة وغير معجزة أيضاً. ويفرّق الجابري بين المعجزة التي تقع للنبي

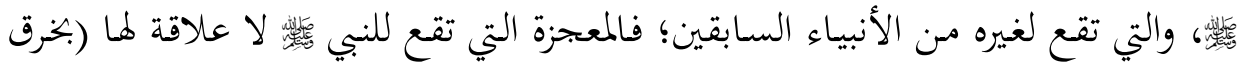

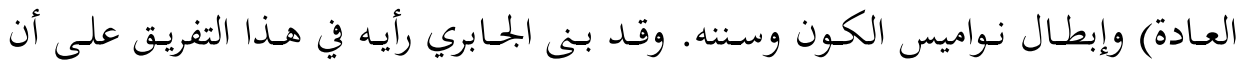

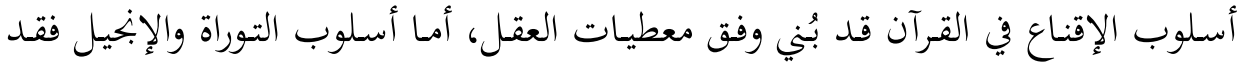

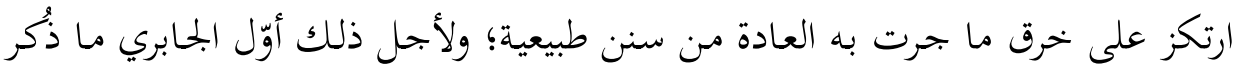

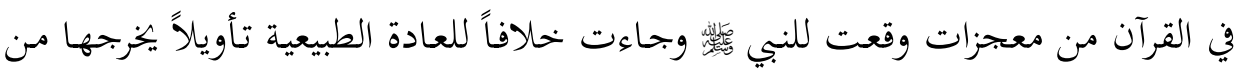

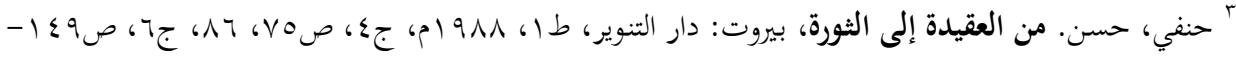
.10. " تقديم عبد البجيد الشرفي على كتاب:

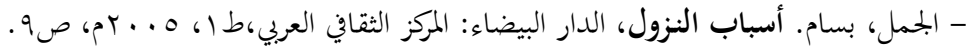

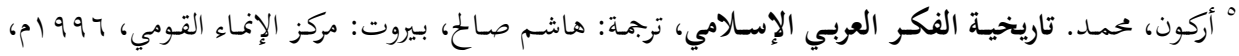

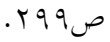

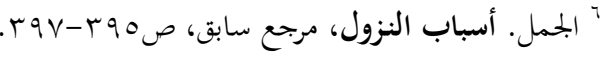

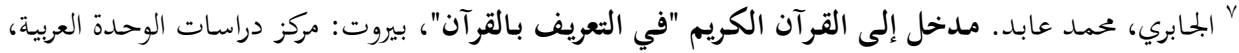

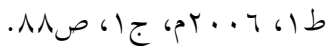




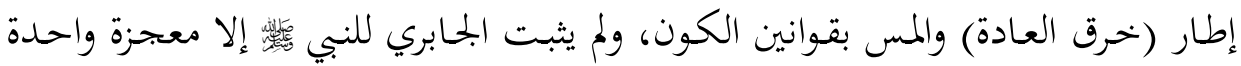

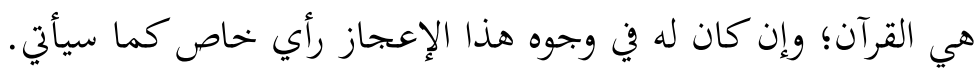

\section{أولاً: إعجاز القرآن عند الجابري}

تفرَّد النبي أس عن جميع الأنبياء والمرسلين بمعجزة باقية على وجه الدهر، صحيحة

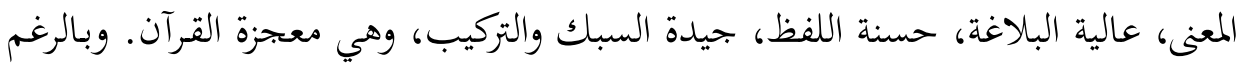

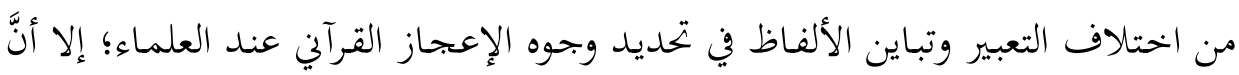

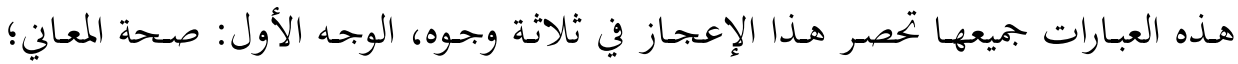

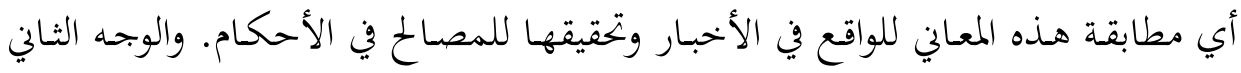

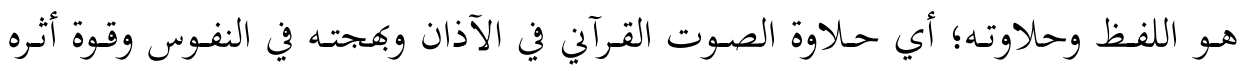

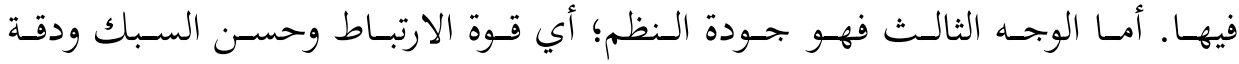

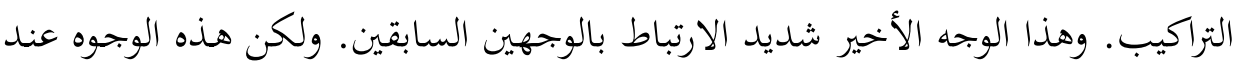

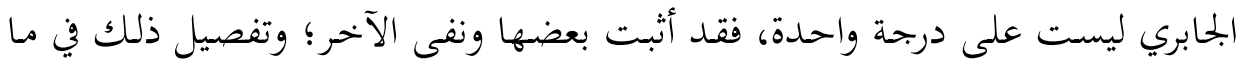

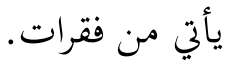

\section{1. الإعجاز اللفظي عند الجابري:}

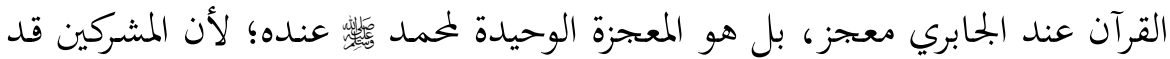

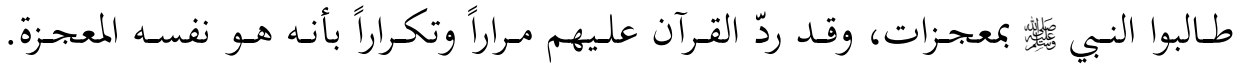

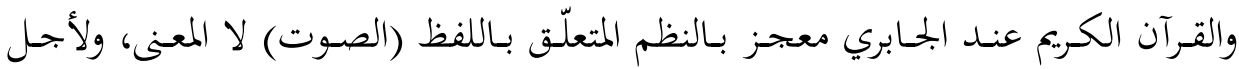

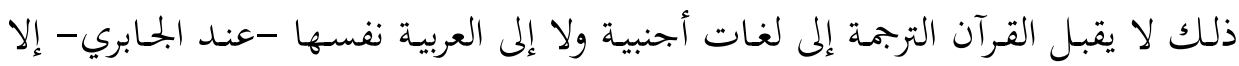

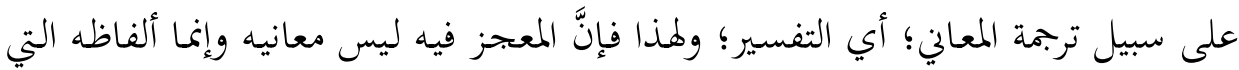

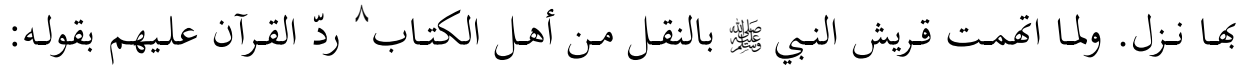

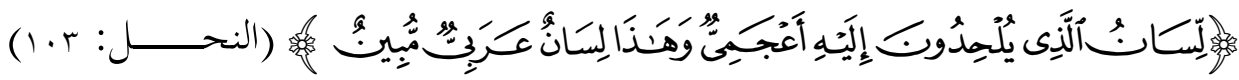

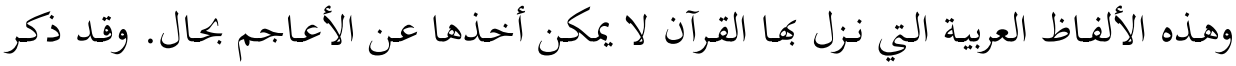




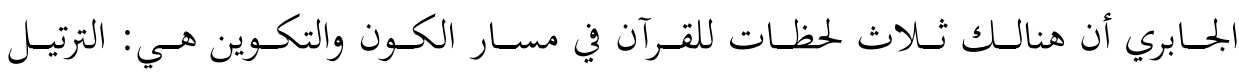

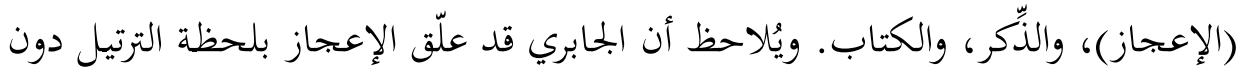

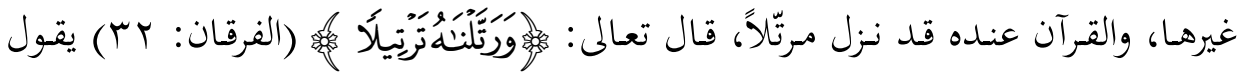

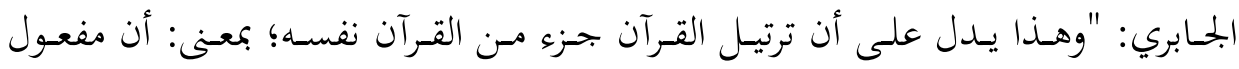

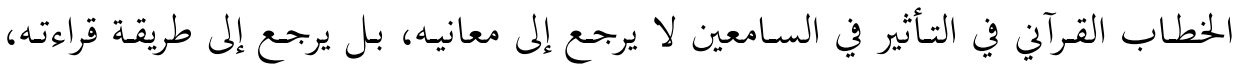

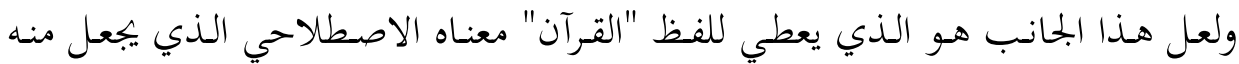

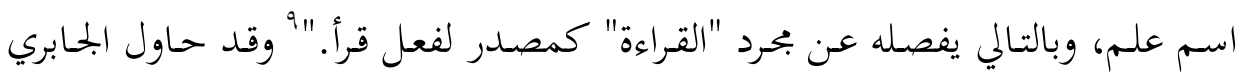

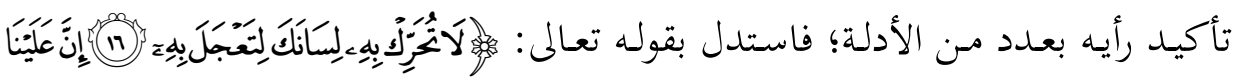

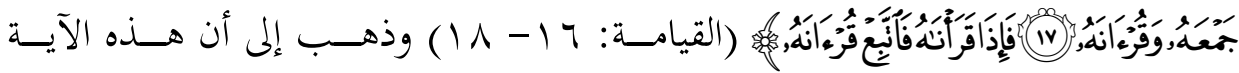

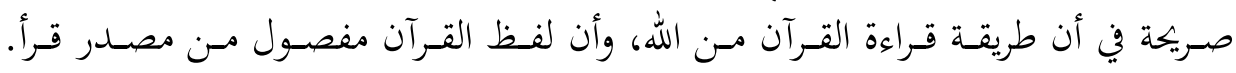

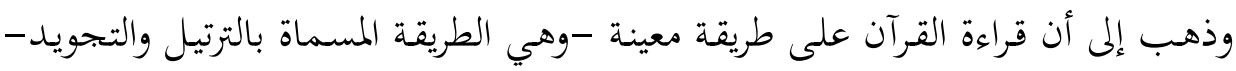

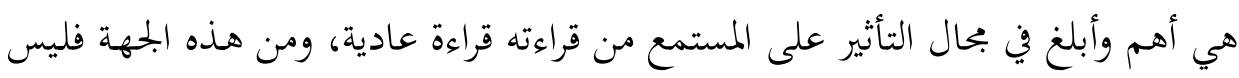

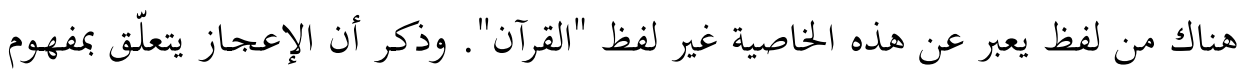

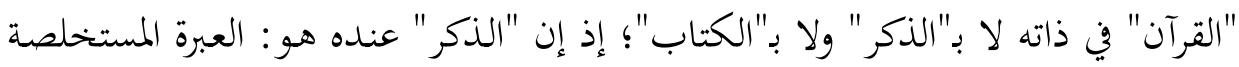

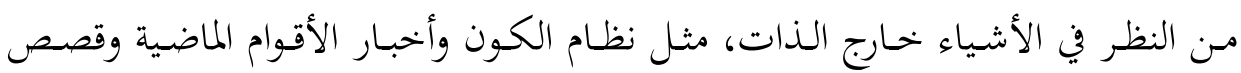

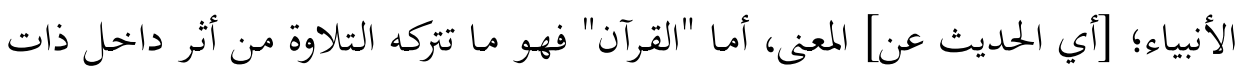

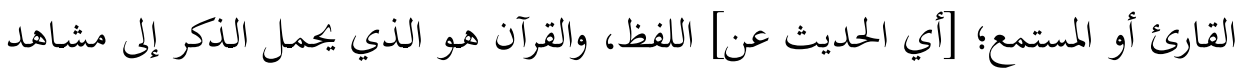

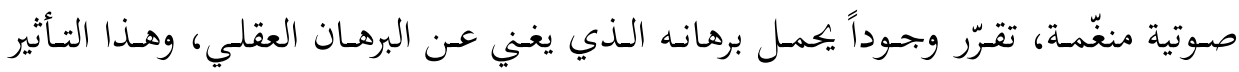

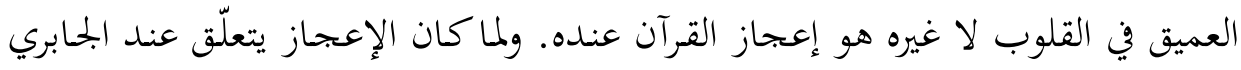

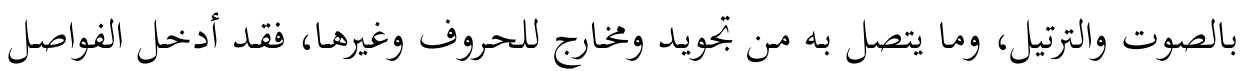

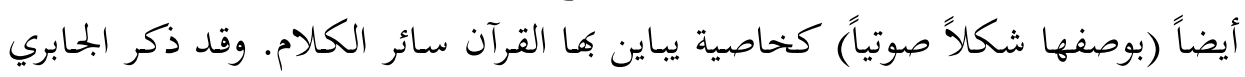

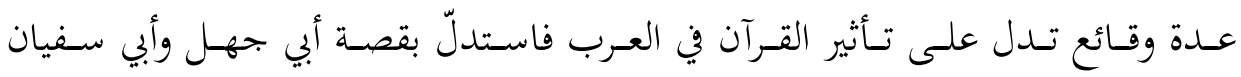

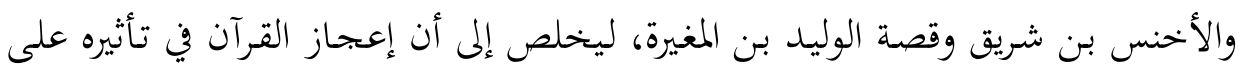
المستمعين، كامنْ في الترتيل لا غيره. '. 
والحق أن الإعجاز الصوتي وجه من وجوه الإعجاز التي أشار إليها العلماء وتناولوها

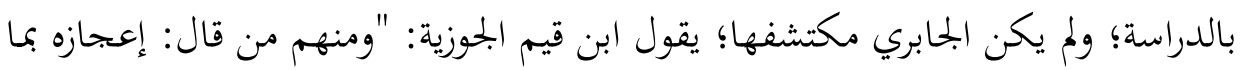

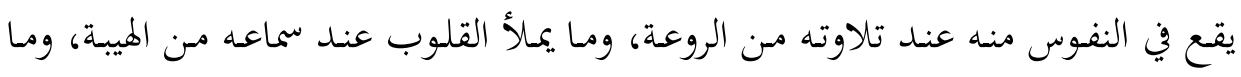

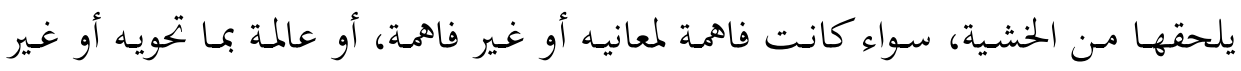
عالمة، كافرة بما جاء به أو مؤمنة." 'ل إلا أن الجابري قد سلك في إثبات هذا النوع من الإعجاز مسلكاً عجيباً، وكانت

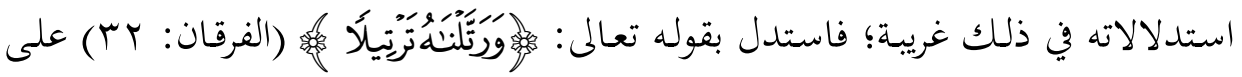

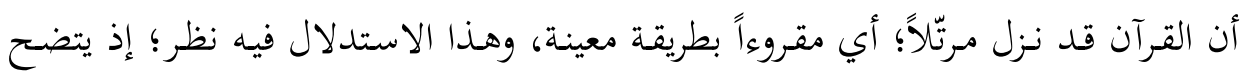

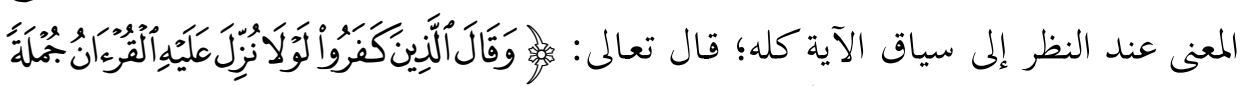

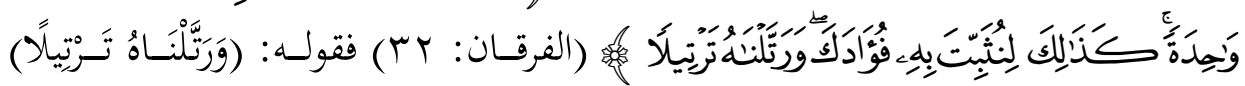

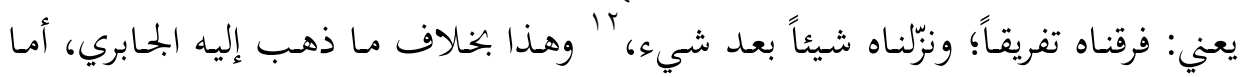

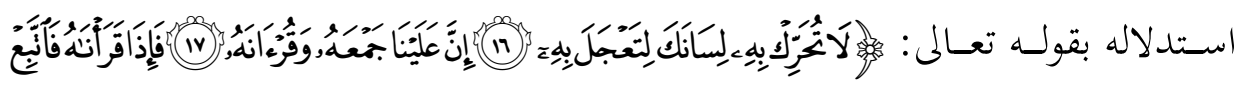

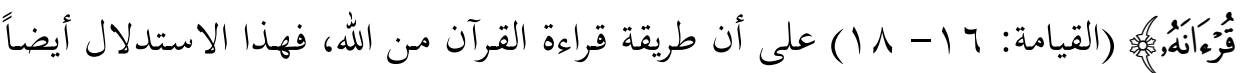

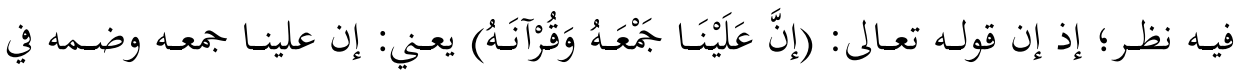

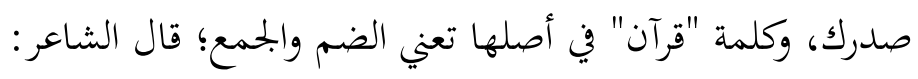
هجان اللون لم تقرأ جنينا ذراعي عيطل أدماء بكر

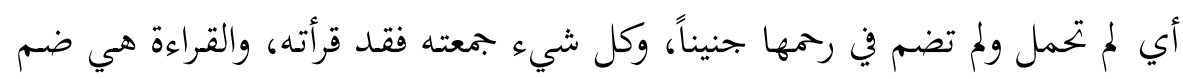

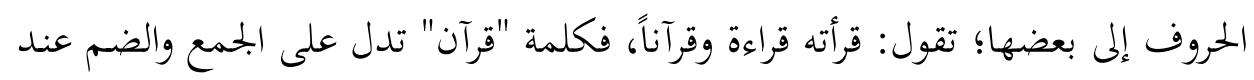

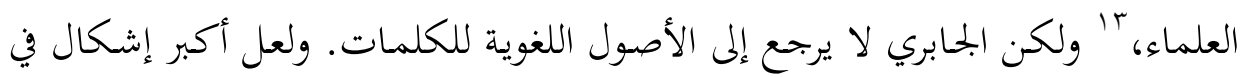

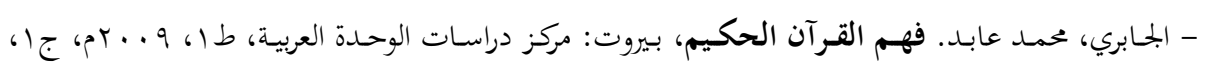

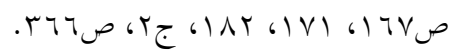
"' ابن قيم الجوزية، محمد بن أبي بكر الزرعي. الفوائد المشوقة إلى على إنوم القرآن، بيروت: دار ومكتبة الهلال، د.ت، ص إگr. r' القرطبي، محمد بن أمدا، بن أبي بكر. الجامع لأحكام القرآن، تحقيق: هشام سمير البخاري، الرياض: دار عالم

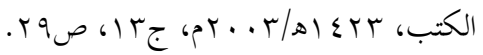

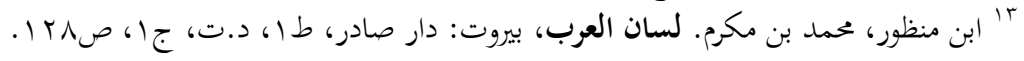


هـذا الإعجـاز اللفظي -عنــ الجـابري- هـو قصـره للإعجـاز في هـذا الوجـه دون سـاه، فالإعجاز اللفظي وجه من وجوه الإعجاز وليس هو الإعجاز كله.

\section{Y. - إعجاز المعنوي عند الجابري:}

لما جعـل الجـابريٌٌ الإعجـاز في (الترتيـل) وفي (القـرآن) مفهومـاً خاصـاً عنـده يتعلّق

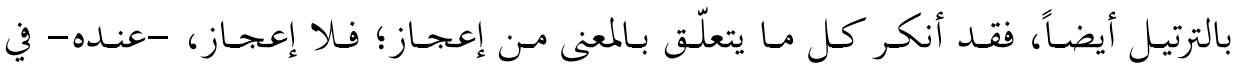
القصص التي جاء بها القرآن، ولا إعجاز في ما جاء به من علوم ومعارف.

ذكر العلماء أن إخبـار القرآن بـالغيوب شكل مـن أشكال إعجـازه المتعلّقـة بـالمعنى، وهو من أبرز أشكال الإعجاز عندهم. وقد كان هذا الوجه مسلّمة من مسلّمات العلماء الذين درسوا الإعجاز، ولم يتم التنازع فيه كما تمّ في غيره من وجوه الإعجاز الأخرى. إلا أن الجابري قد ذهـب إلى أن (الإعجاز) في أول أمره كان مقتصراً على التأثير في القلوب

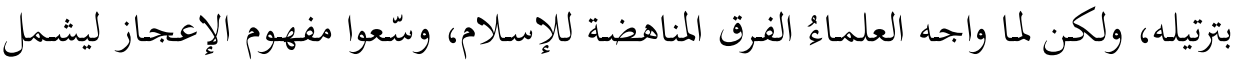

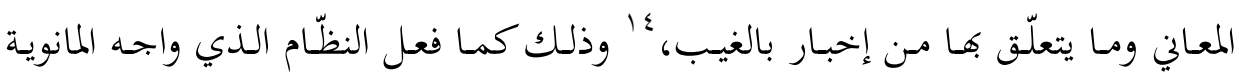
الذين طعنوا في القرآن.

والحق أن الإعجاز المتعلّق بالمعاني وما يتصل بها من إخبار بالغيب هو أظهر وجوه

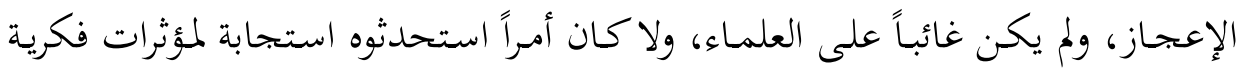
معينة؛ بل كان أمراً بدهيّاً موجوداً في القرآن نفسه، وغاية ما في هذا الأمر أن إبراهيم بن سيار النظّام القائل بـ"نظرية الصِّرفة"، قد مال إليه دون غيره رافضاً للنظم وغيره من وجوه

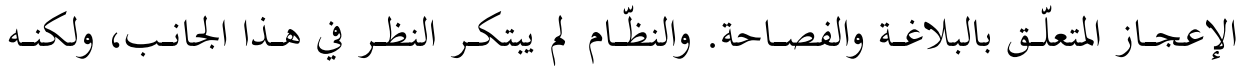
اقتصر عليه بناء على مؤثرات فكرية معينة، فالاقتصار على هذا الجانب المعروف المشهور من الإعجاز -ـوليس الانتباه إليه- هو الذي كان نتيجة هذه المؤثرات. وقد ركّز الجابري

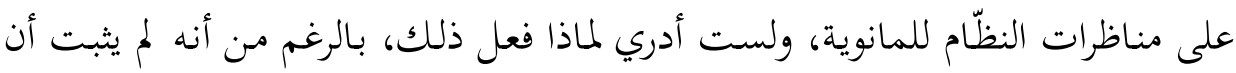


المانوية قد هاجموا إعجاز القرآن، وإنما كانوا فرقة من الفرق التي ناظرها النظّام في عقائدها لا في إعجاز القرآن

والإخبار بالغيب يتعلّق بالأخبار والقصص الماضية والمستقبلية التي حكاها القرآن،

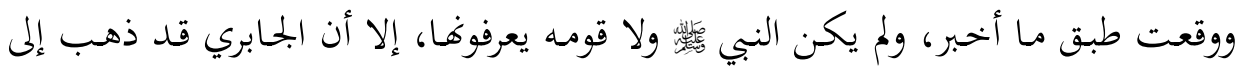

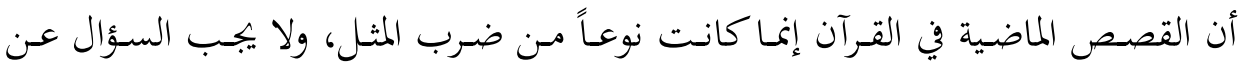

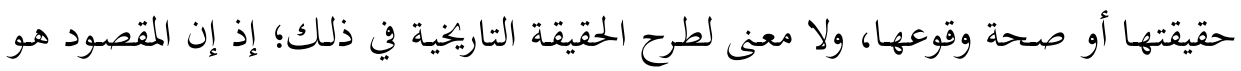

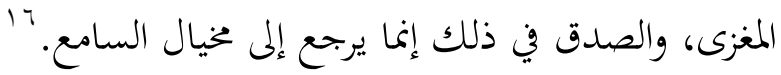
وإذا كان الجمابري يقصد بضرب المثل في القصص، أن هذه القصص كانت تتنزّل

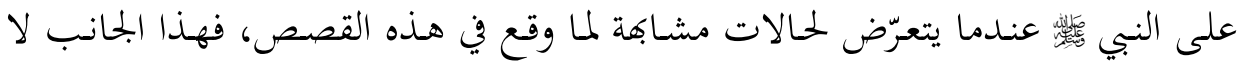

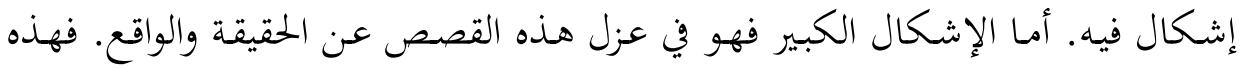

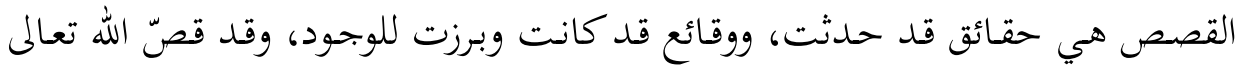
لنبيه

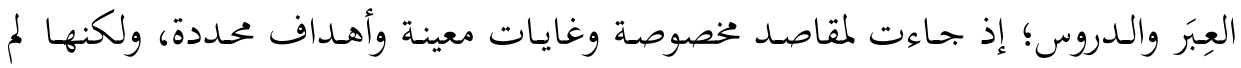

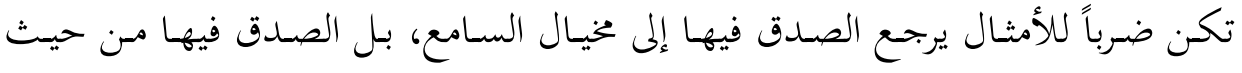
مطابقتها للواقع.

والقصص القرآنية عند الجابري ليست جديدة على الناس عندما حكاها القرآن؛ إذ

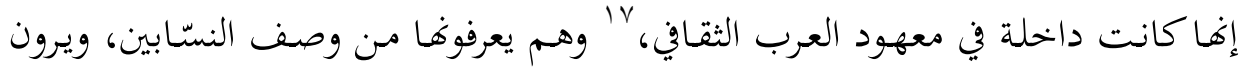

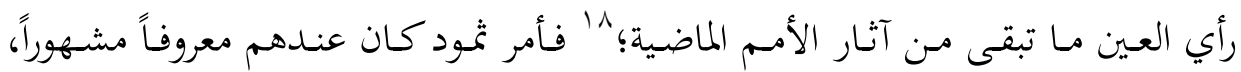

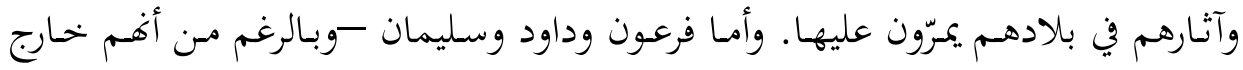

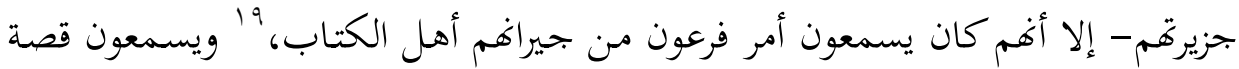

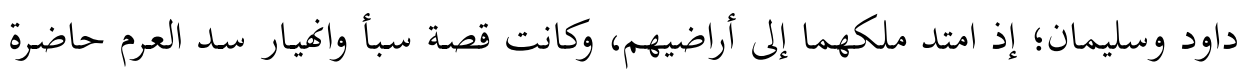

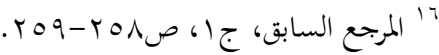

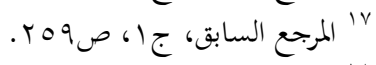

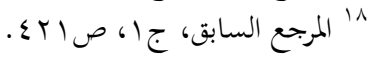

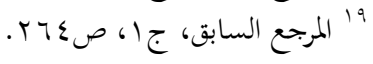




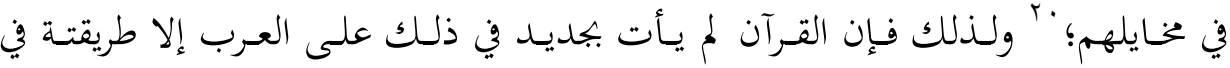
عرضه وتلاوته لهذه القصص على شاكلة معينة.

والحق أن ما ذكره الجابري فيه نظر؛ إذ إن العرب لم يكونوا يعرفون القصص الماضية،

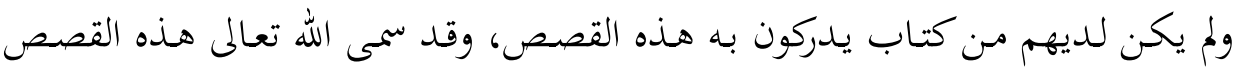

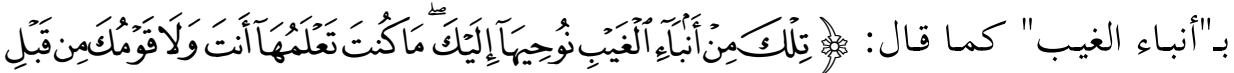

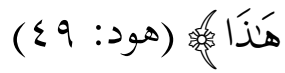
وقد ذهـب الجمابري إلى أن أهل الكتاب أيضاً كانوا يعرفون القصص التي وردت في

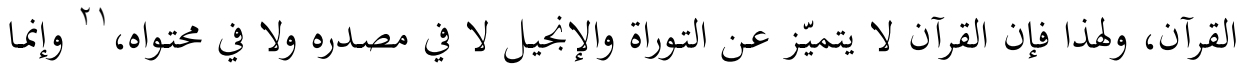

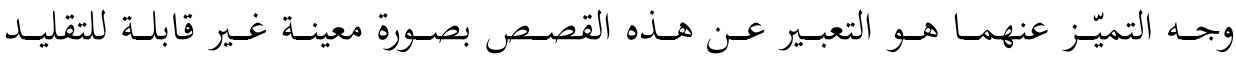

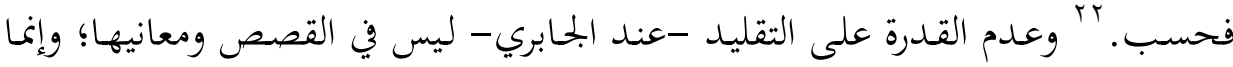
في الوجه الوحيد للإعجاز عنده وهو الترتيل والتلاوة.

وما ذهب إليه الجابري من مساواة بين القرآن والتوراة والإنجيل في هذه القصص ليس

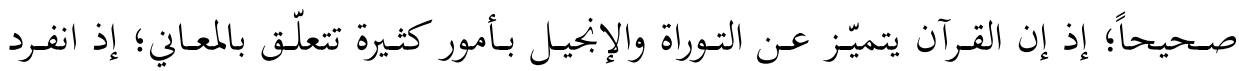

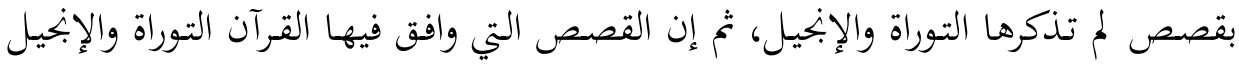

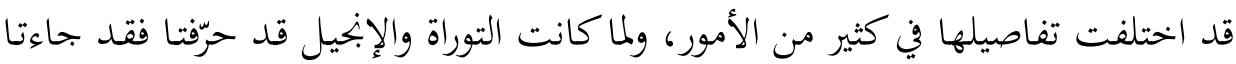

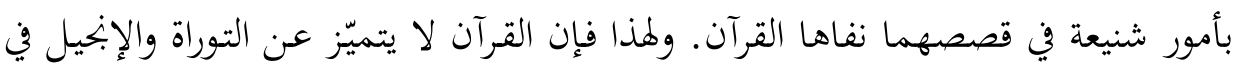

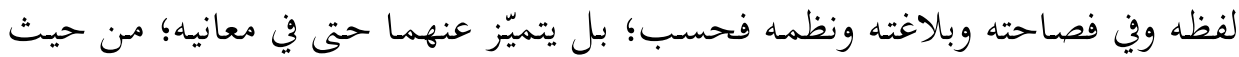
صدق أخباره وعدل أحكامه.

\section{r. الإعجاز العلمي عند الجابري:}

إن علاقة القـرآن بـالعلوم -على انحتلاف أنواعهـا- علاقـة وثيقـة، وقيـام الإعجـاز

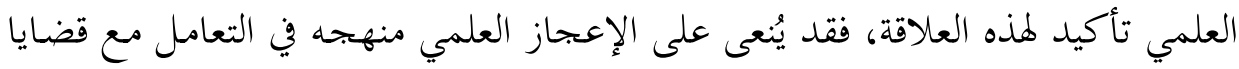

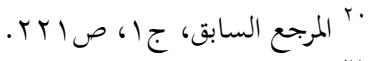

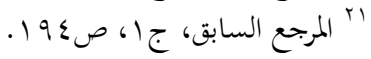

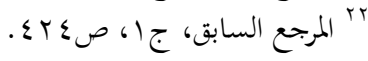


العلوم في القرآن، وقد يُنعى عليه بعض معالجاته لعدم التزامها بالضوابط والشروط اللازمة

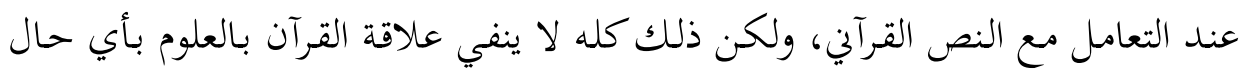

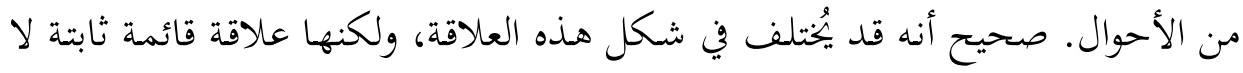

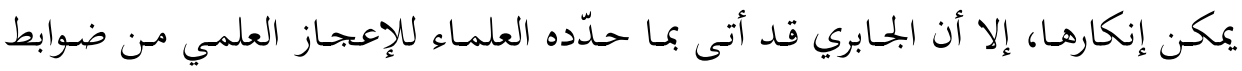

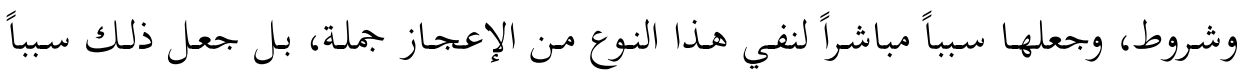

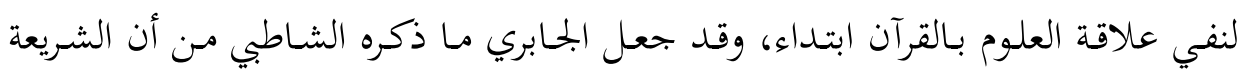

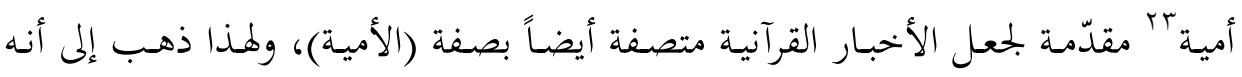

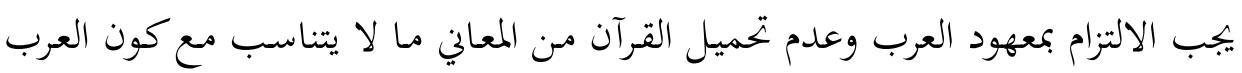

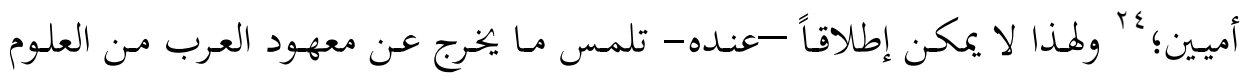

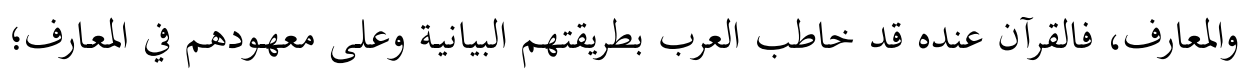

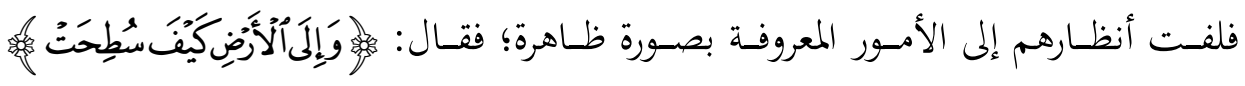

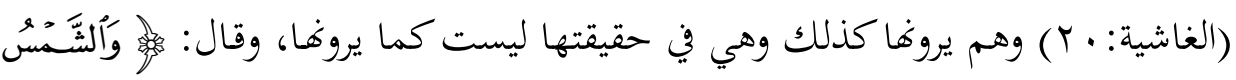

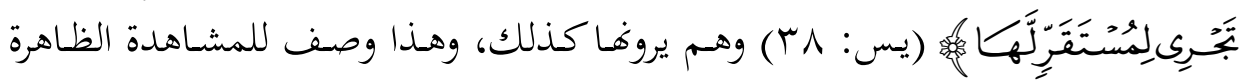

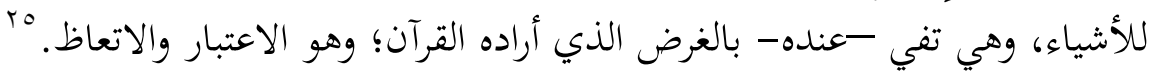

وقد ذهب الجابري إلى أنه إذاكانت معرفة لغة العرب ضرورية لفهم القرآن، فكذلك

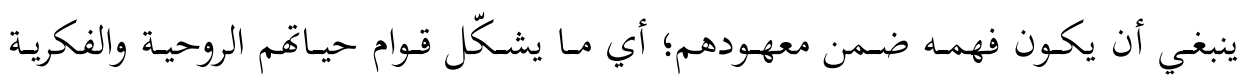

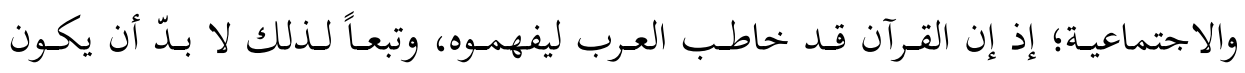

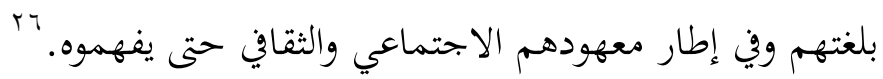

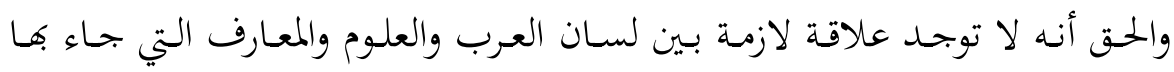

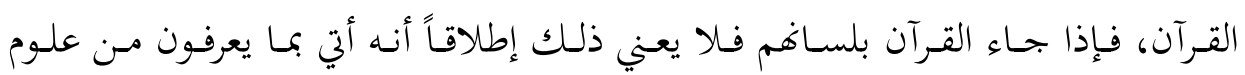

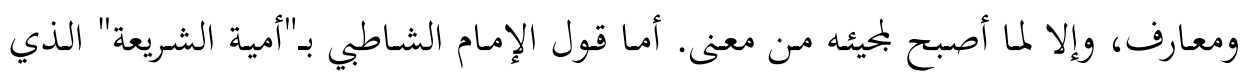

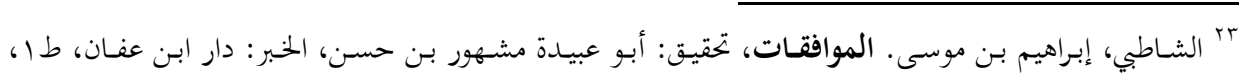

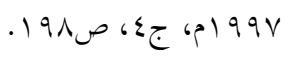

${ }^{25} \mathrm{http} / / / \mathrm{www}$. aljabriabed.net/index.htm

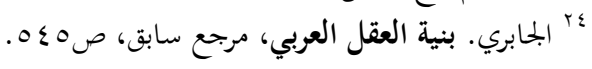

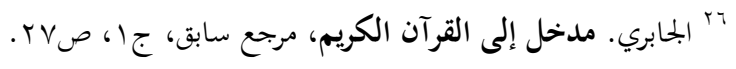




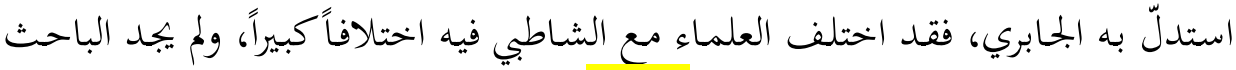
أحداً من العلماء نقل قول الشاطبي إلا ليعترض عليه.

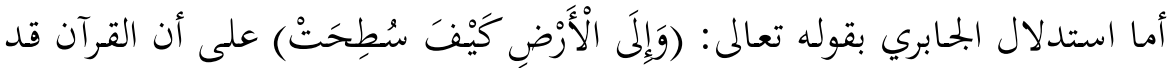

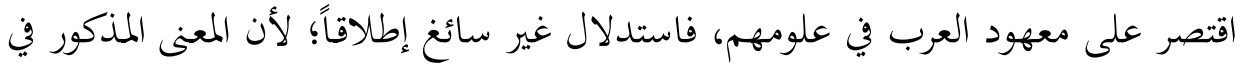

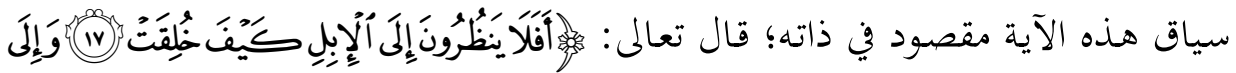

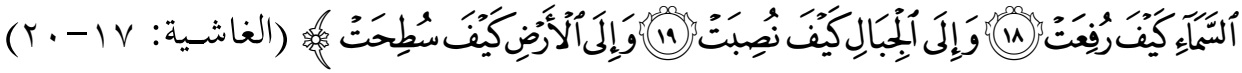

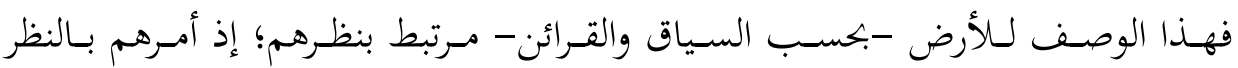

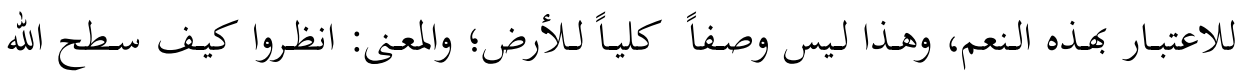

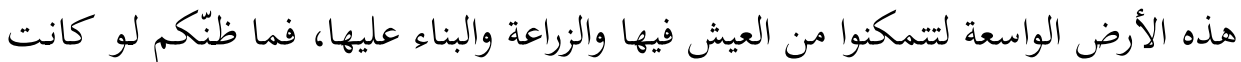

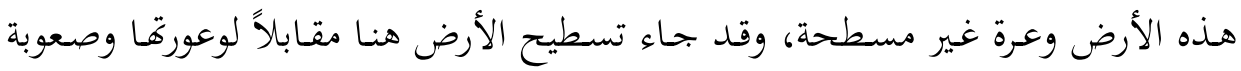

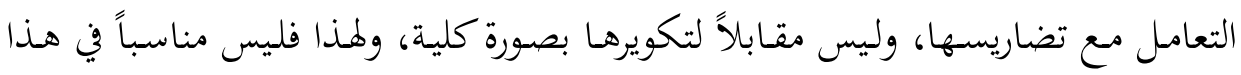

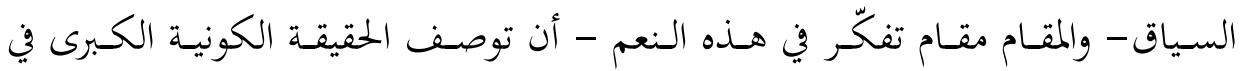

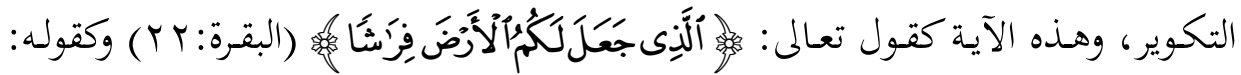
لَكَ

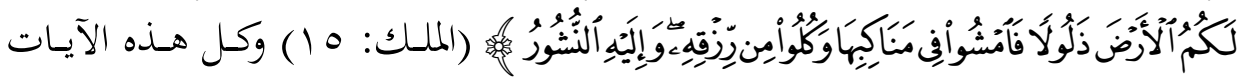
قد جاءت في إطار التفكر في نعم الله تعالى. لألى

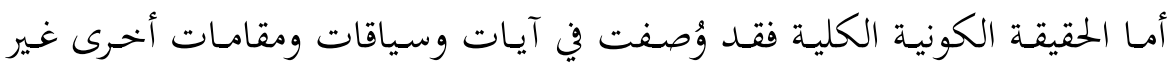

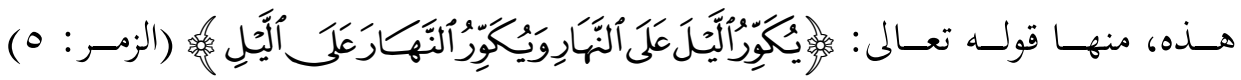

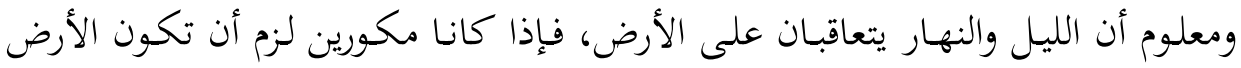

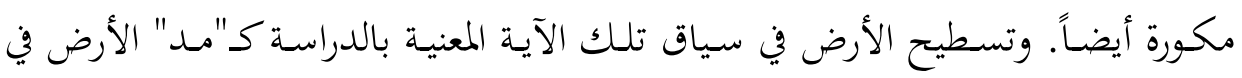

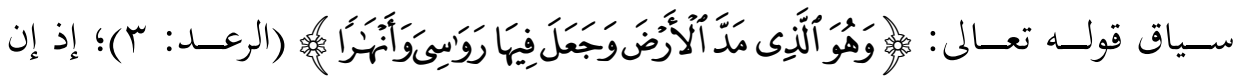

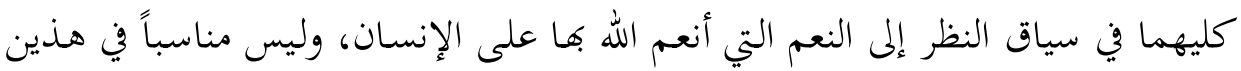

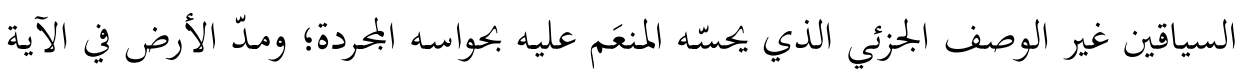

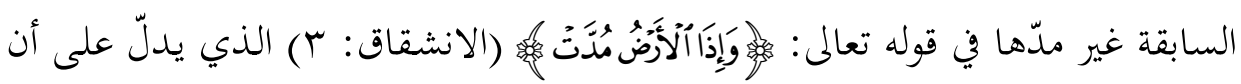




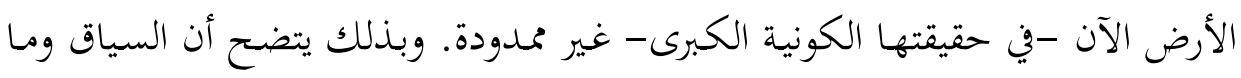

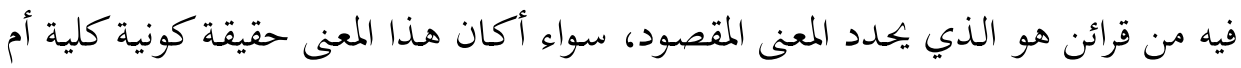
حقيقة كونية نسبية يراها المخاطب.

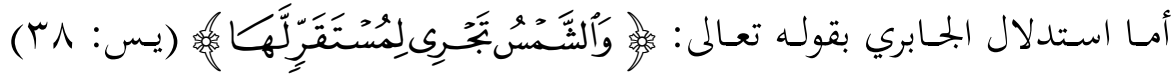

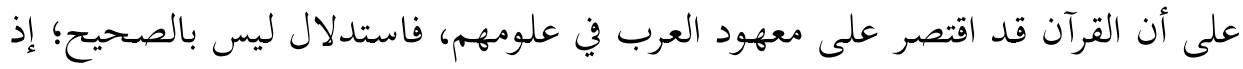

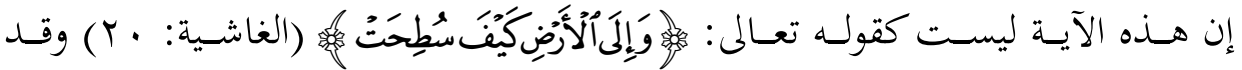

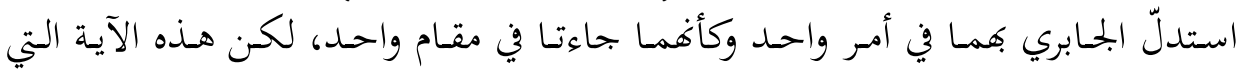

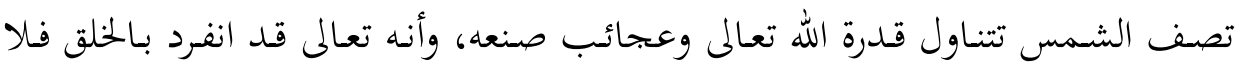

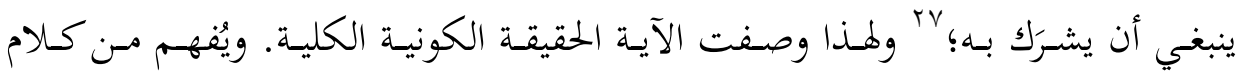

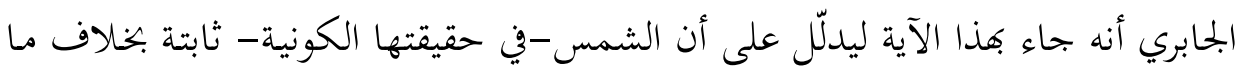

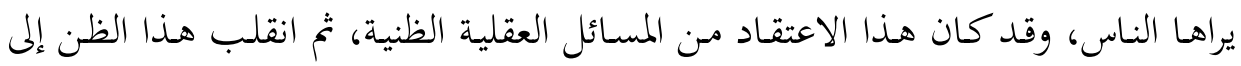

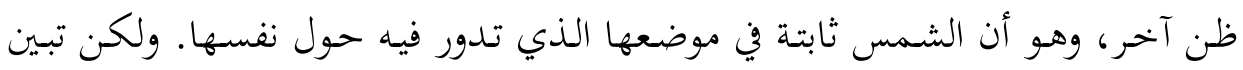

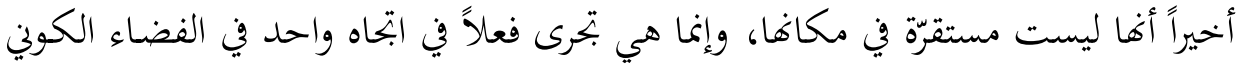
الهائل.

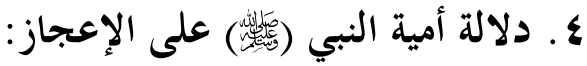

ذهب الجابري في كتابه (مدخل إلى القرآن الكريم) الذي أراد به تقديم القرآن للقارئ

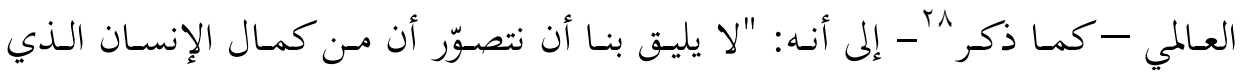

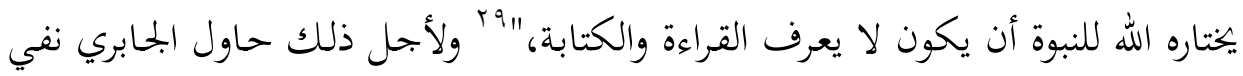

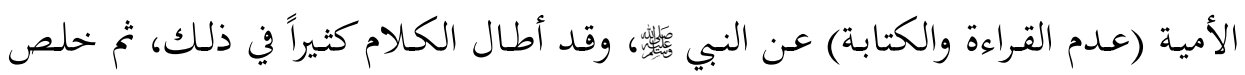
إلى أنه لا علاقة بين صفة "الأمية" هذه و "المعجزة".

وقد حاول الجابري الإتيان بكافة الأدلة التي تثبت دعواه في نفي "الأمية" عن النبي 

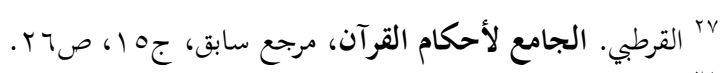

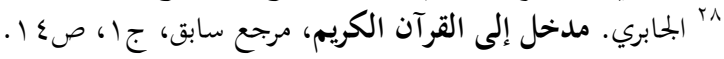

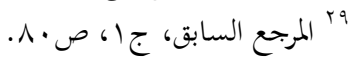


ابن إسحاق-: (ماذا أقرأ؟) بالصيغة الاستفهامية، مما يدلّ على أنه كان يعرف القراءة، في حين أن رواية البخحاري: (ما أنا بقارئ)، ولأجل ذلك ذلك ذهـب الجحابري إلى حمل رواية البخاري على رواية ابن إسحاق؛ فذكر أنه من الممكـن أن تكون هذه العبارة الواردة في

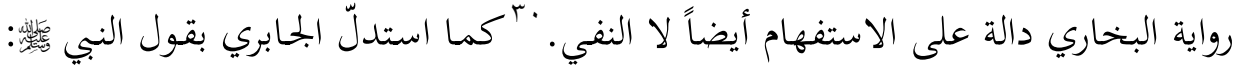
"فجاءلي جبريل وأنا نائم بنمط من ديباج فيه كتاب" وقوله: "هببـت من نومي فكأنما

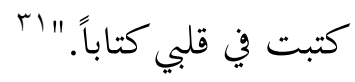

وقــ ذهـب الجـابري إلى أن القـراءة والكتابـة كانست منتشـرة بـين العـرب؛ فالخلفـاء

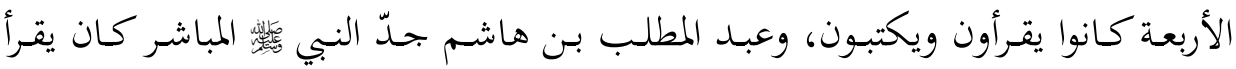

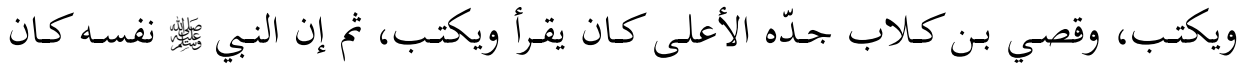

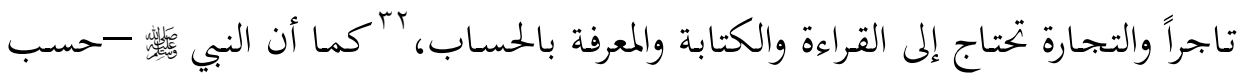
ما ذكر الجابري- قد محا لفظ (رسول الله) عن اسمه في صلح الحديبية حينما رفض علي

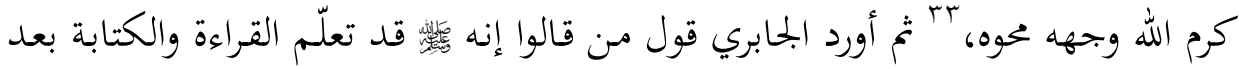
النبوة، بعد أن كان قبلها أمياً، فذكر قول الألوسي: "ومعجزة الكتابة بعد أميته لا تنافي

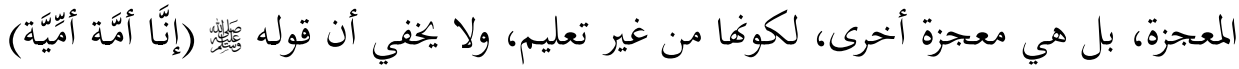

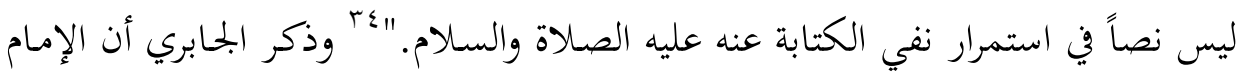

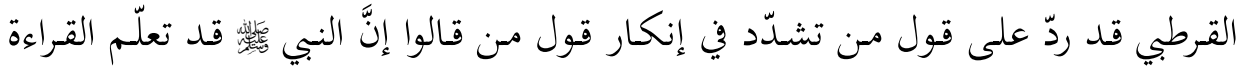
والكتابة، يقول الجـابري: "وفي هـذا الابتحاه علّق القرطبي على رأي مـن ينكر القول بـأن النبي (الأمي) الذي وُصف به النبي

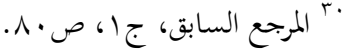

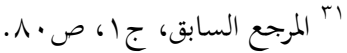

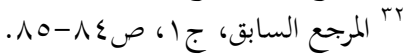

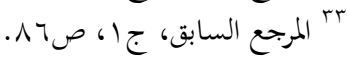

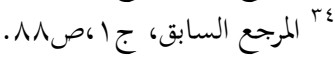

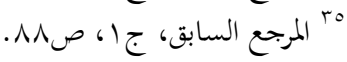


عـدم المعرفـة بـالقراءة والكتابـة، بـل إن لفظظ "الأميـين" يعـني في القـرآن: الـذين ليس هـم كتاب، جَّ وأن لفظ (أمي) نفسه إنما هو لفظ معرَّب لا أصل له في العربية.

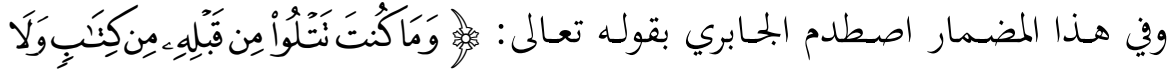

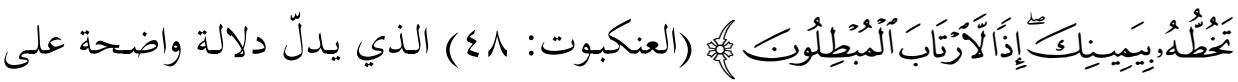
أمية النبي تفسير (روح البيان) للإتيان بمثال على هذا التخبّط؛ إذ أورد صاحب (روح البيان) قول

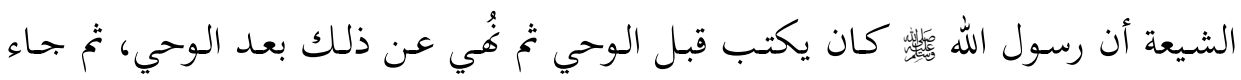
الجـابري بمـا نقله صـاحب (روح البيـان) مـن صـاحب (الأسئلة المقحمـة) ^بـ مـن أن أهـل

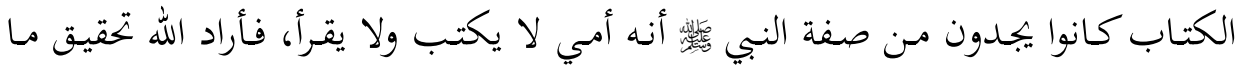

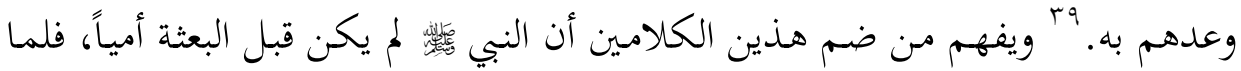
بُعث وكان وصفه في التوراة والإنجيل أنه أمي، امتنع عن الكتابة والقراءة، وهذا عجيب جداً.

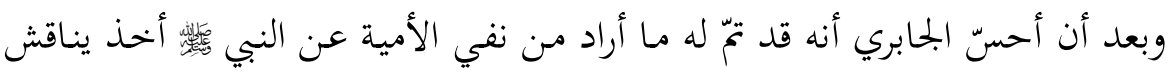
علاقة الأمية بالإعجاز، فذهب إلى أنه لا علاقة للأمية بعدم القدرة على الإتيان بالبلاغة العالية والفصاحة السامية؛ إذ إن شعراء العرب وخطباءهم كانوا يقولون الشعر ويخطبون اربتالاً من دون إعداد لا قولاً ولا كتابة؛؛ “؛ فـلّ ذلك -عنده- على أنه لا علاقة بين الأمية والإعجاز . - الإن.

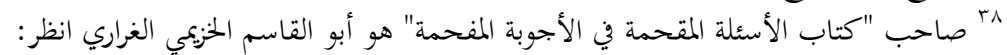

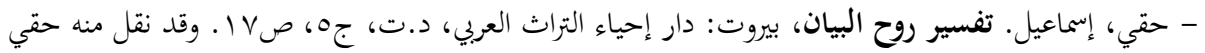

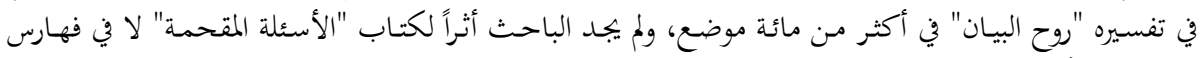

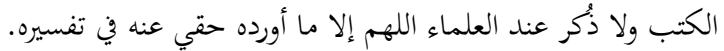

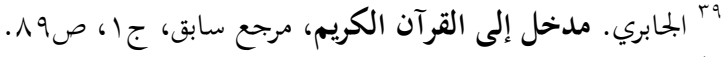

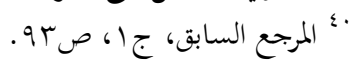




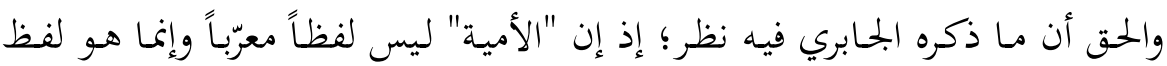

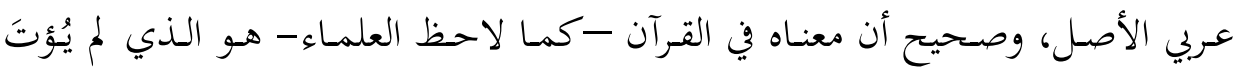

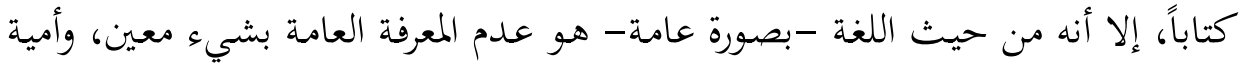

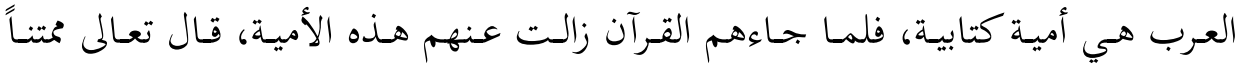

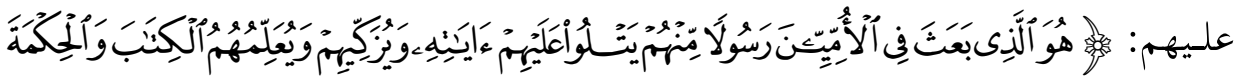

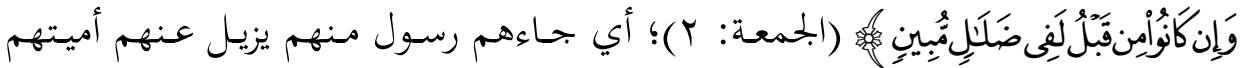
الكتابية هذه. أمـا أميّة القراءة والكتابة فقد كانت شائعة بينهم، وكانت القراءة والكتابة

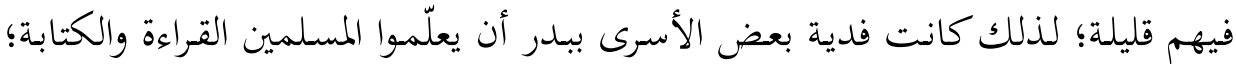
مما يدلّ على أها كانت فيهم نادرة قليلة.

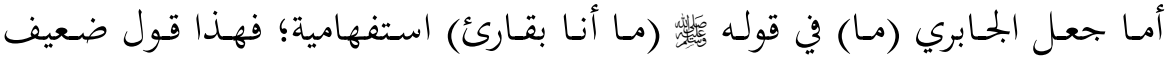

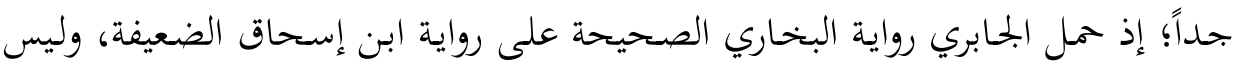

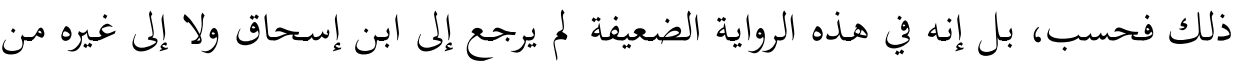

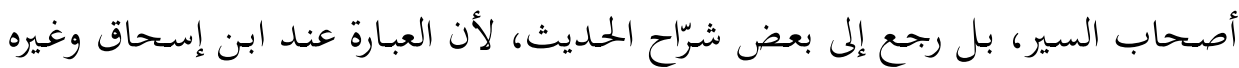

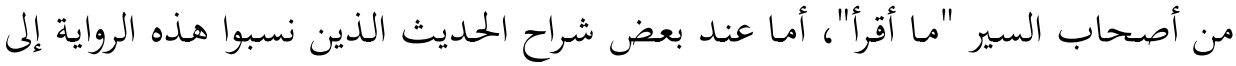

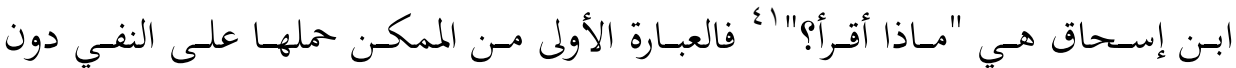

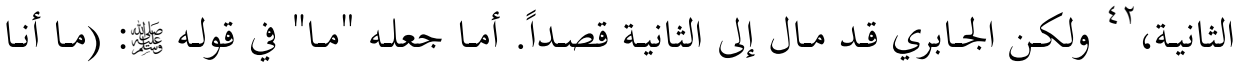

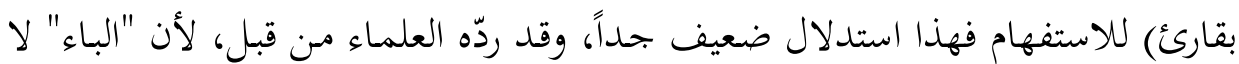

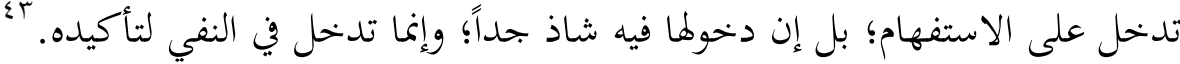

" ليس هذا هو اللفظ الذي أورده ابن إسحاق ولا غيره من أصحاب السير وإنما اللفظ الذي أوردوه هو: (ما أقرأ). انظر:

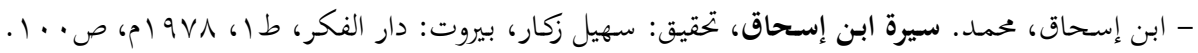

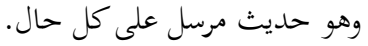

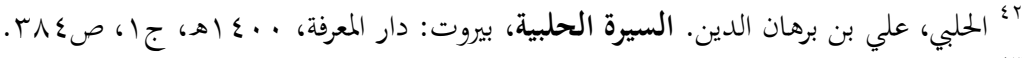

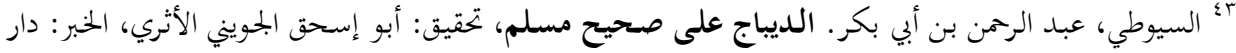

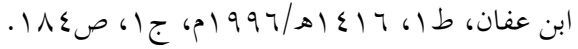




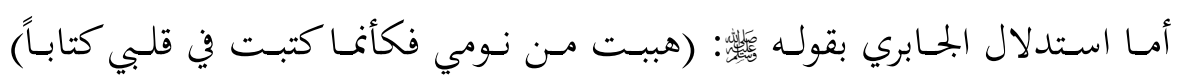

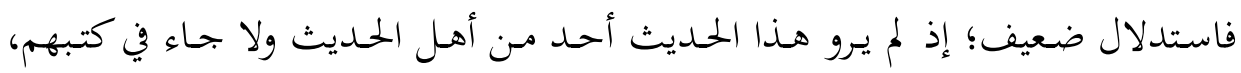

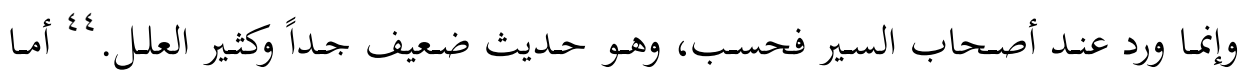

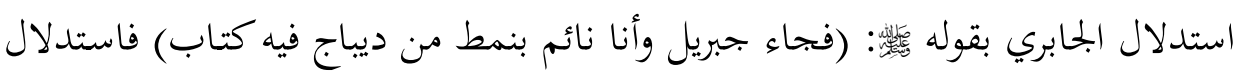

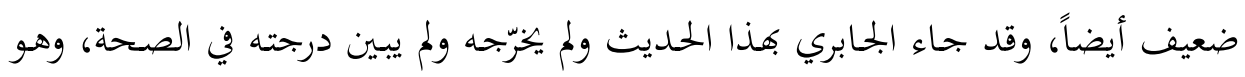

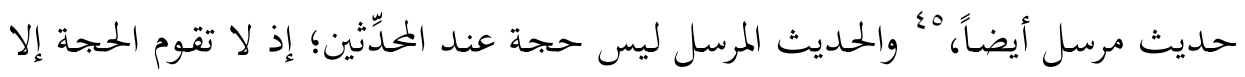

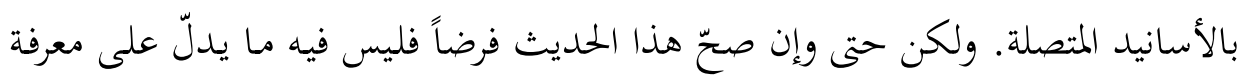

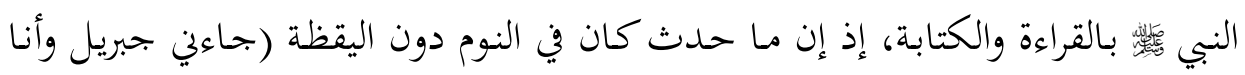

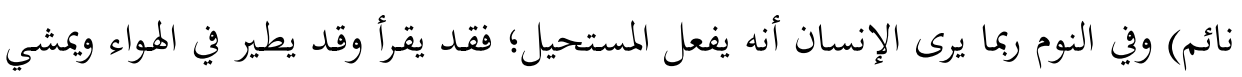

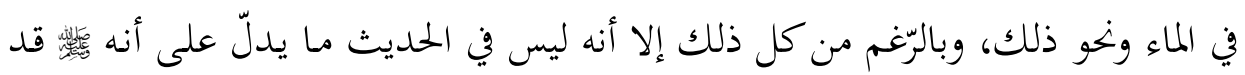

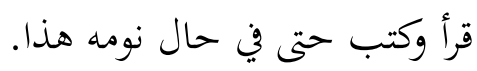

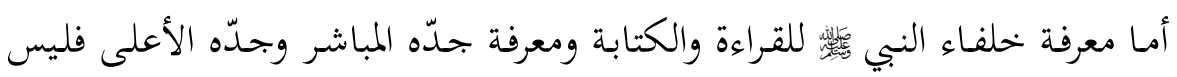

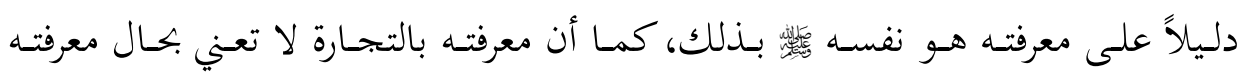

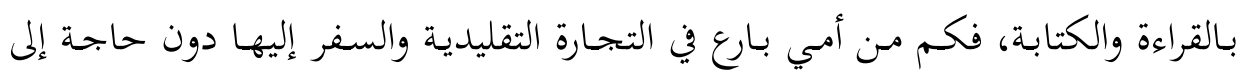

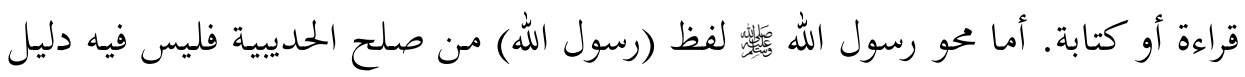

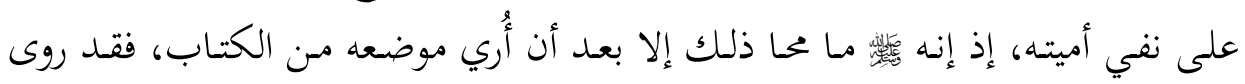

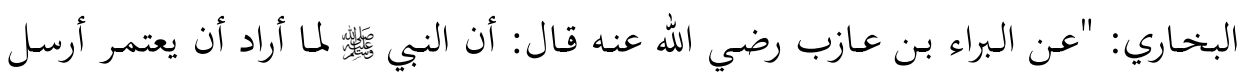

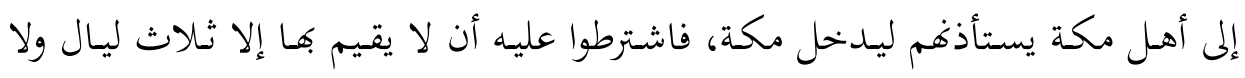

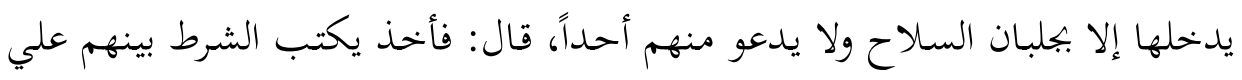

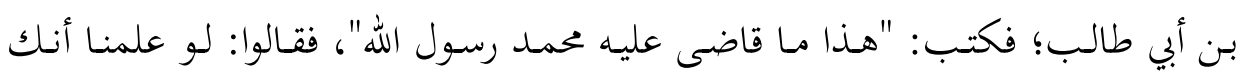

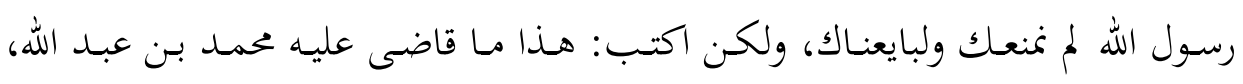

§؛ الألباني، محمد ناصر الدين. سلسلة الأحاديث الضعيفة والموضوعة وأثرها السيئ في الأمة، الرياض: دار

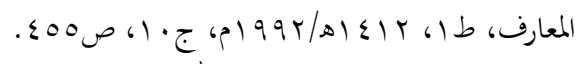

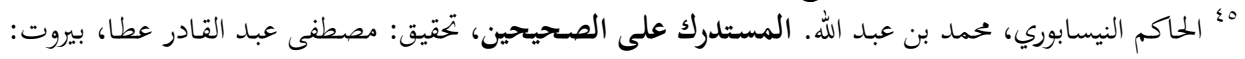

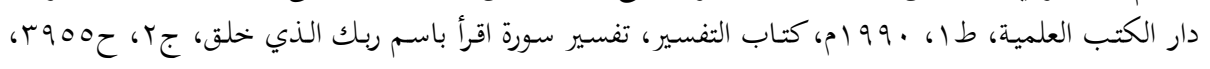




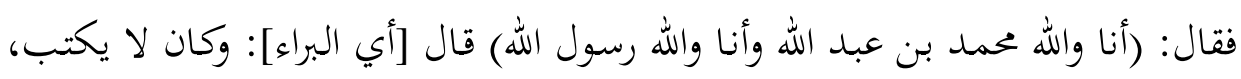

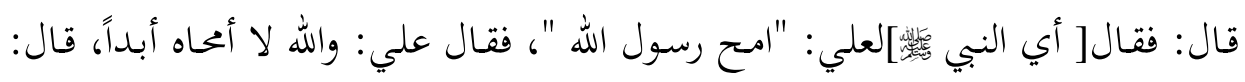

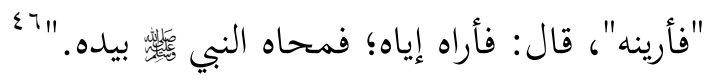

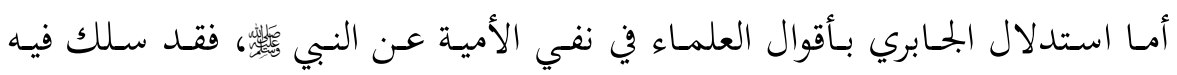

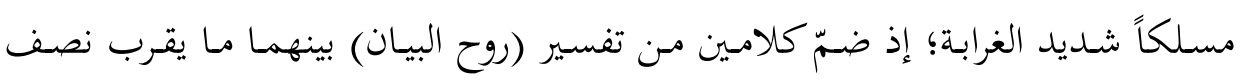

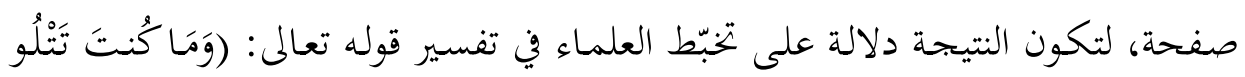

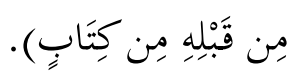

تم جاء الجابري بقولين نسبهما إلى القرطبي والألوسي، وهذه النسبة ليست بالدقيقة

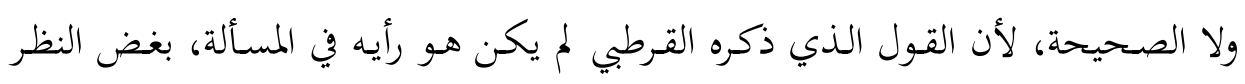

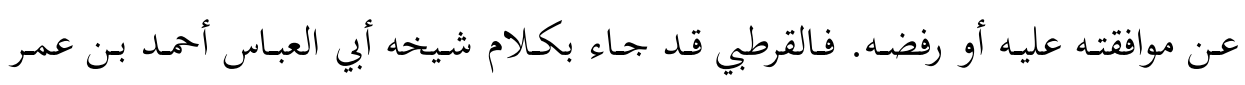

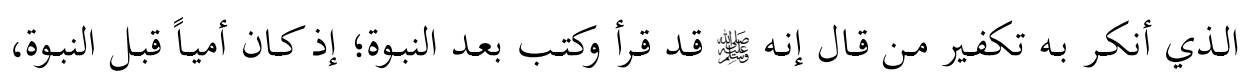

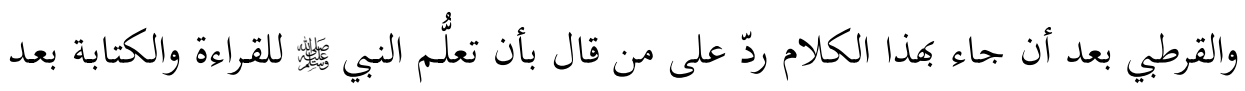

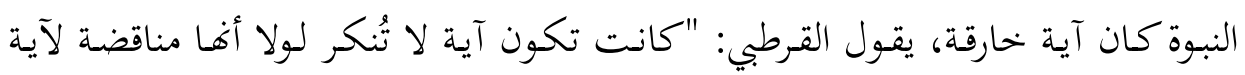

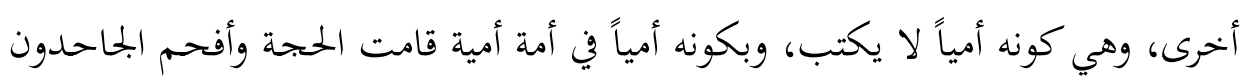

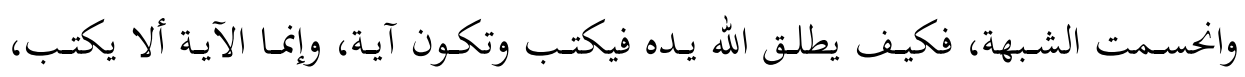

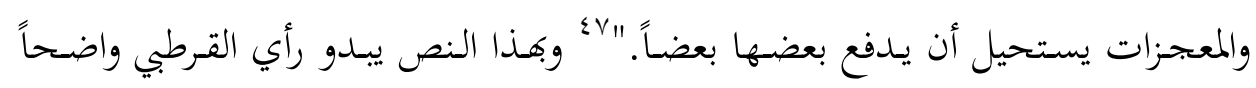

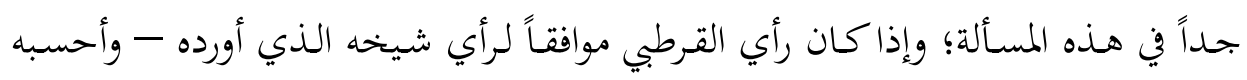

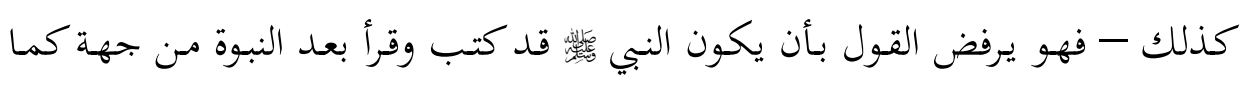

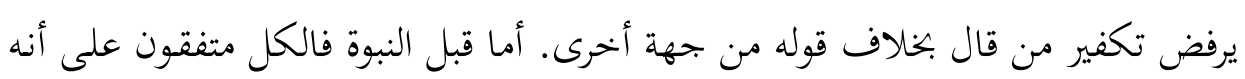
كان أمياً

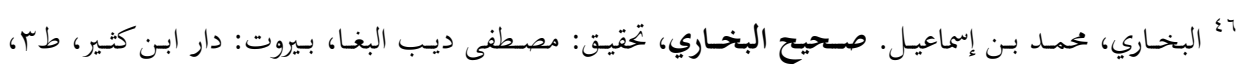

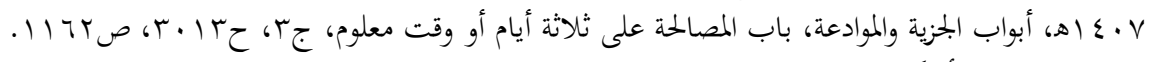

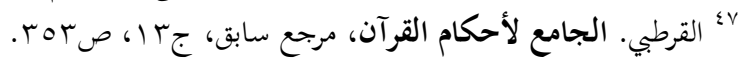




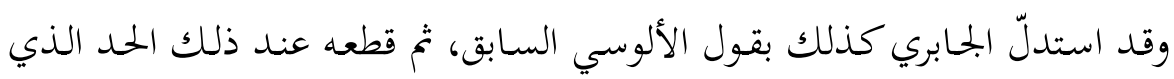

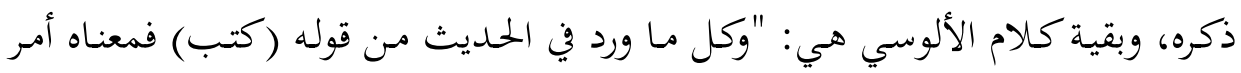

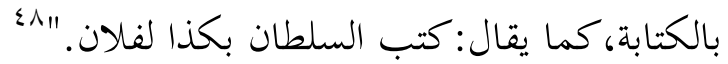

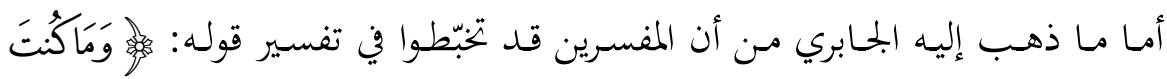

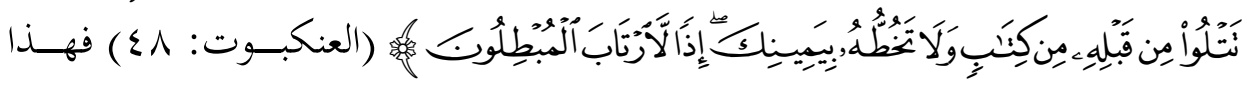

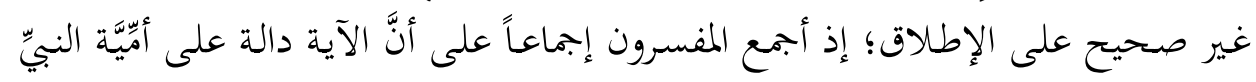

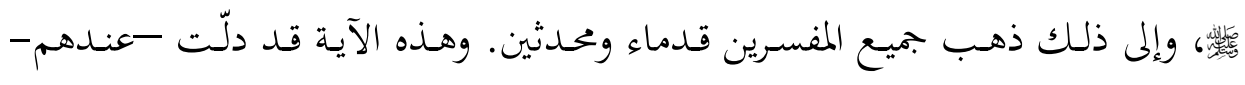

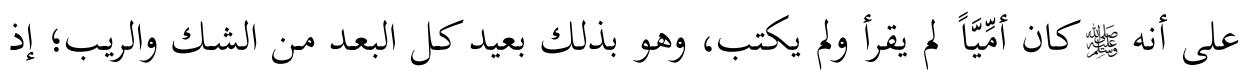

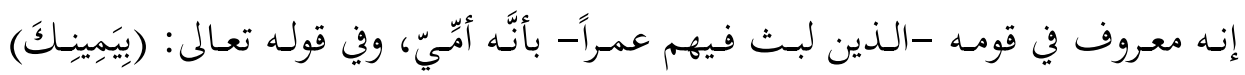

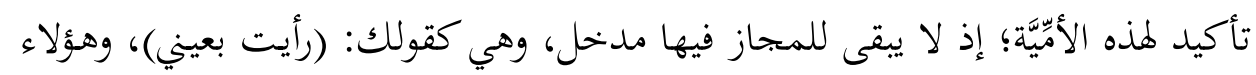

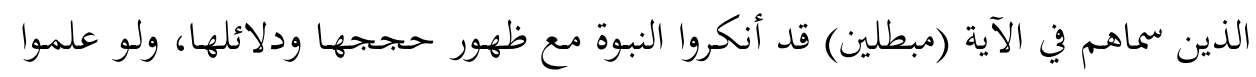

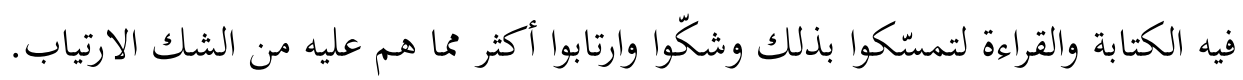
وقد ذهب الجابري إلى أنه لا علاقة بين "الأمية" و"الإعجاز القرآني"، لأن الفصاحة

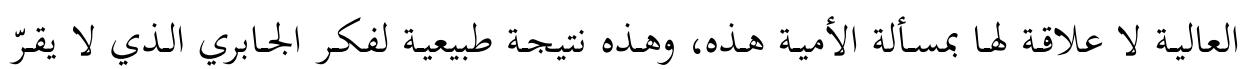

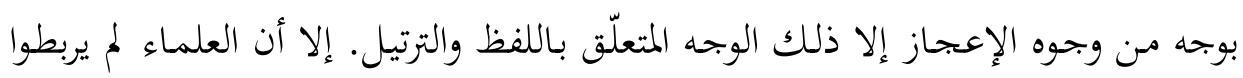

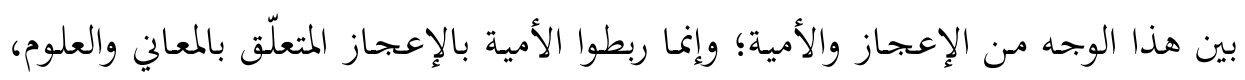

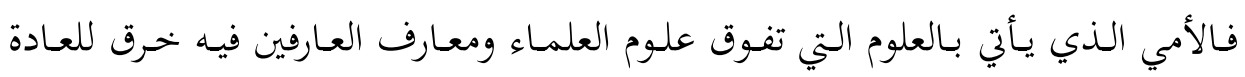

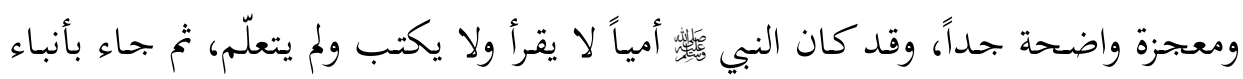

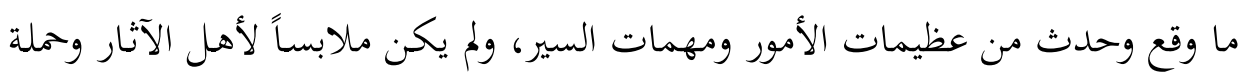

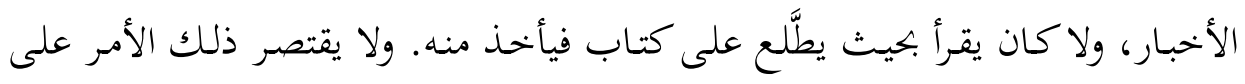

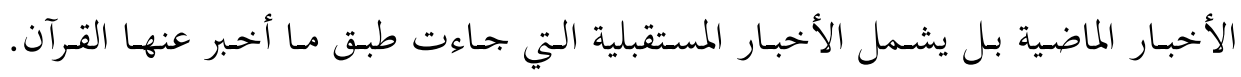

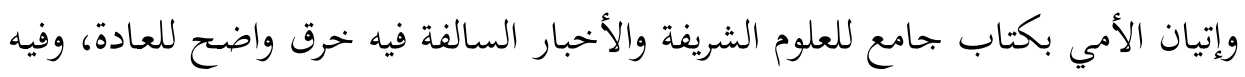

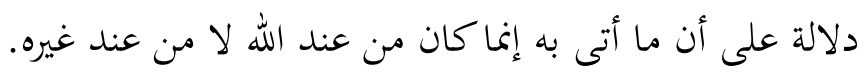

^؛ الألوسي، محمود أبو الفضل. روح المعاني في تفسير القرآن العظيم والسبع المثاني، بيروت: دار إحياء التراث العربي، د.ت، جالب، صه. 
ثانياً: المعجزات الحسية للنبي لكئي

ذهب الجابري إلى أن برهان نبوة محمد لَّ هو القرآن، وليس المعجزات الحسية وخرق

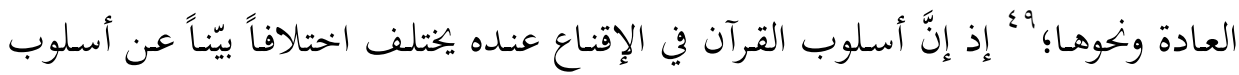

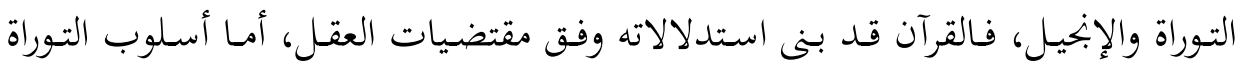

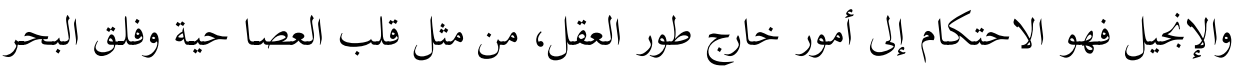

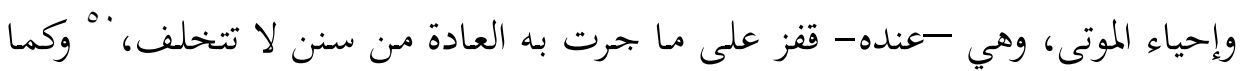

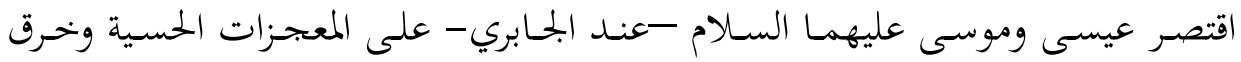

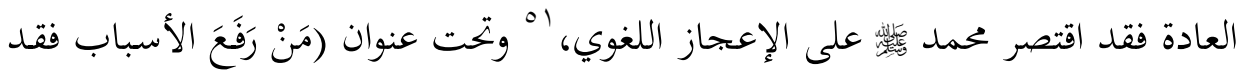

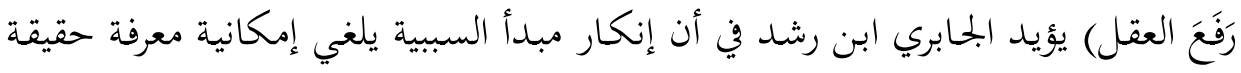

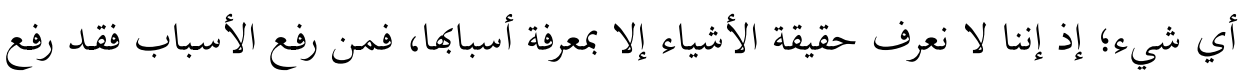

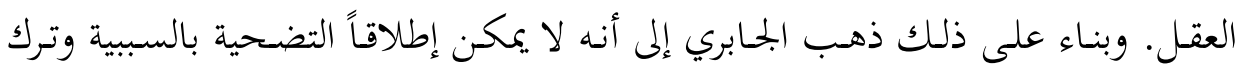

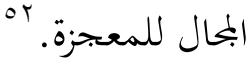

وقد عمد الجابري إلى القرآن لإثبات رأيه في أن النبي

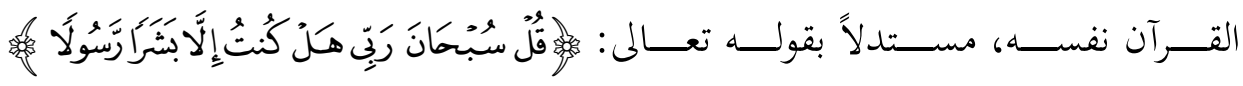

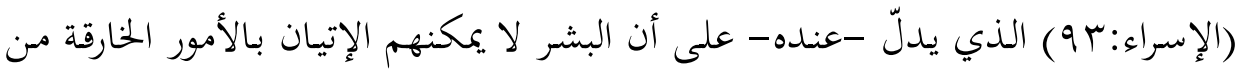

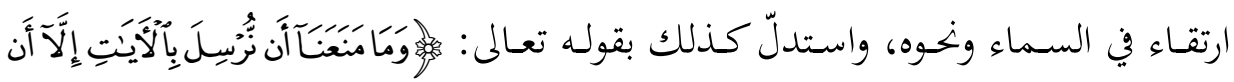

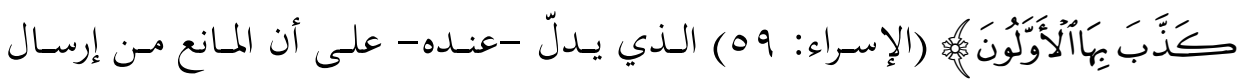

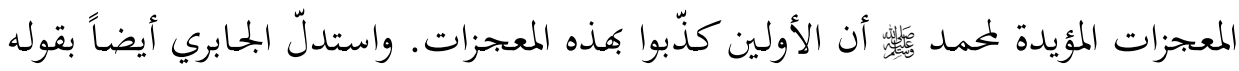

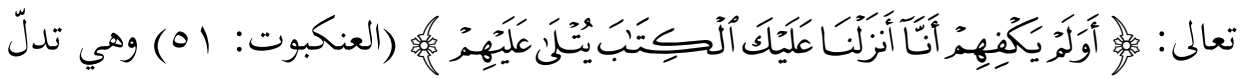
- عنده- على أن محماً

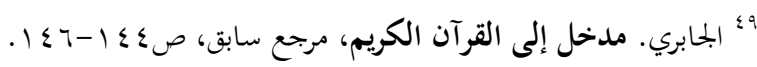

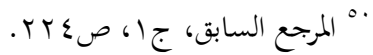

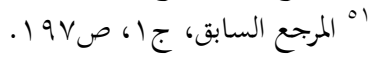

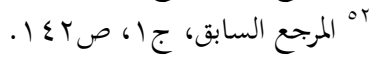




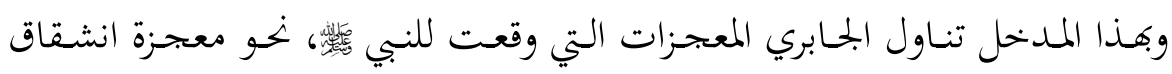

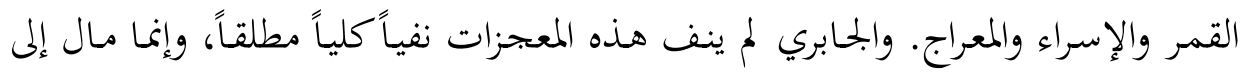

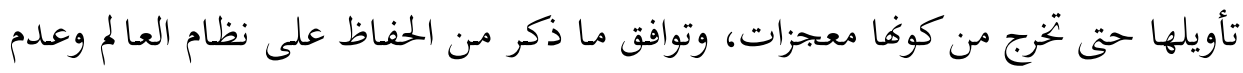

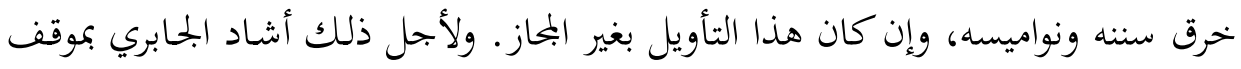

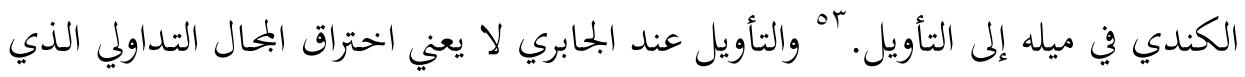

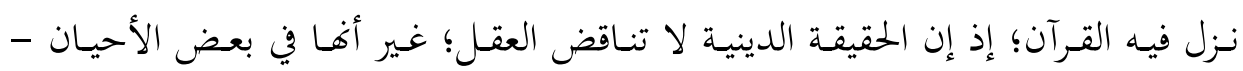
عنده- لا يمكن نيلها من ظاهر النص، بل قد يستلزم الأمر اللجوء إلى التأويل. ويُلاحظ أن الجابري قد أتى من القرآن بالمعجزات التي يمكن تأويلها نحو انشقاق

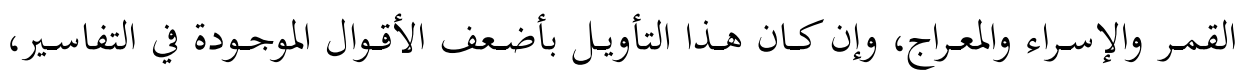
ولكن الجابري تزاور بصورة واضحة وضرب صفحاً عن تلك المعجزات التي ليس للتأويل

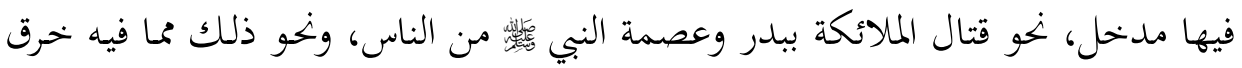

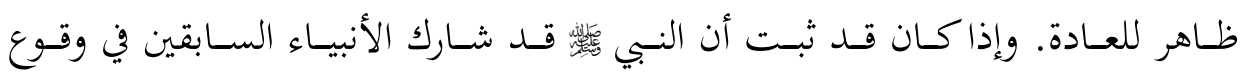
المعجزات الحسية على يديه، كما دلّ على ذلك صريح القرآن وصحيح السنة، إلاّ أنه إنه

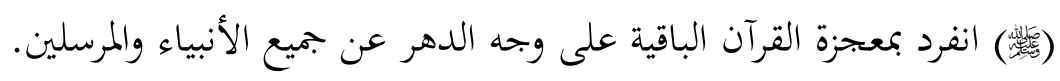

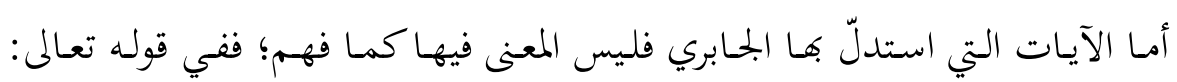

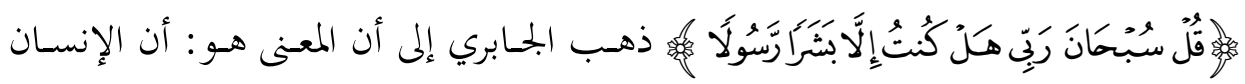

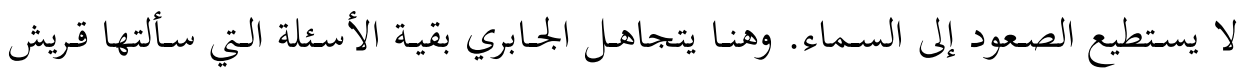

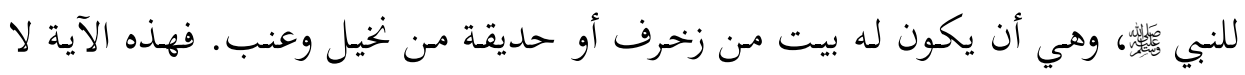

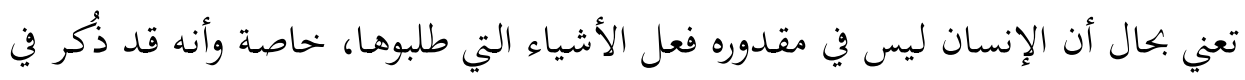

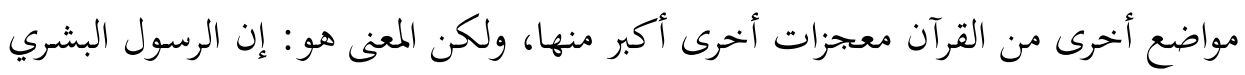

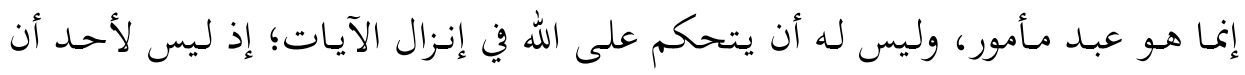

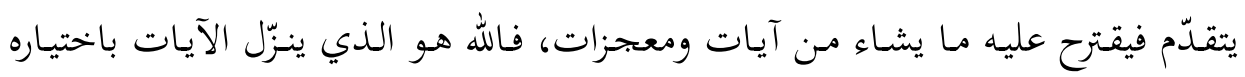

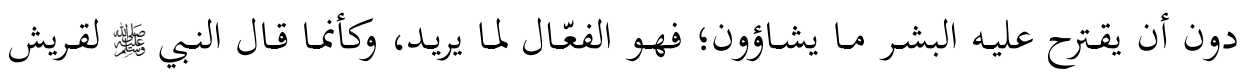


حين اقترحوا عليه ذلك: "هذا سلطان الله وملكوته إن شاء أجابكم وإن شاء لم ميجبكم، إنهاء

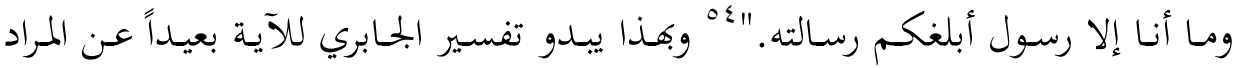
منها.

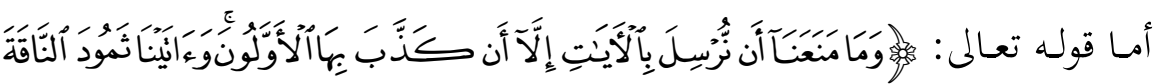

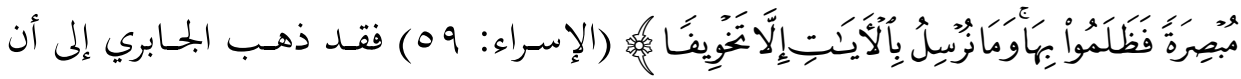

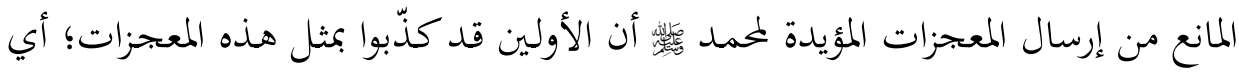

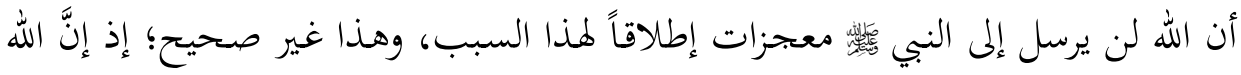

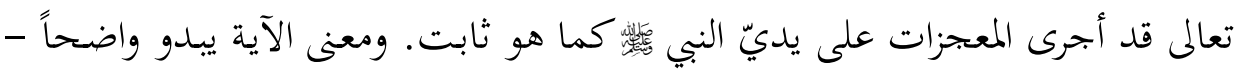

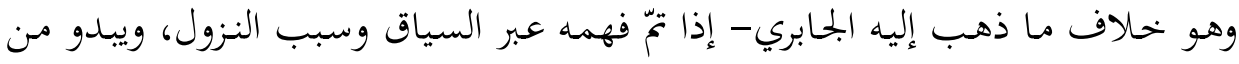

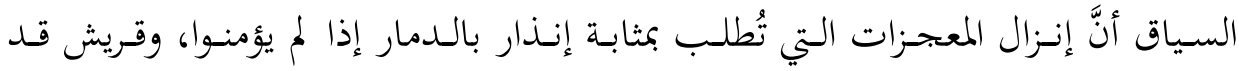

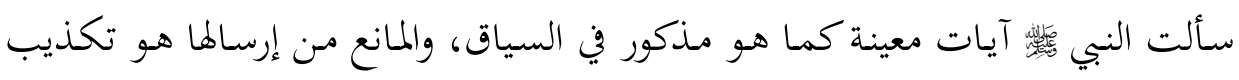

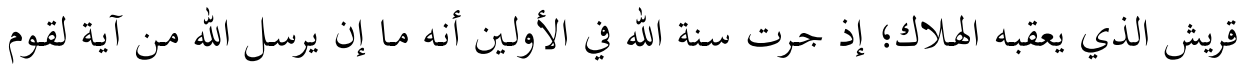

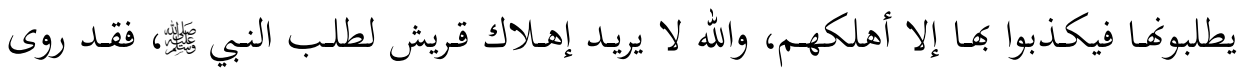

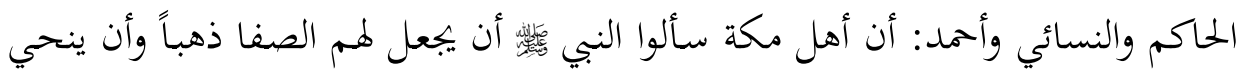

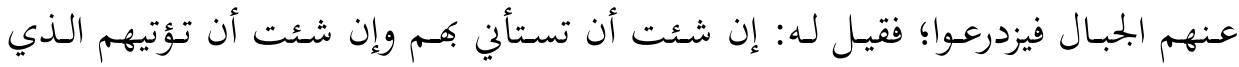

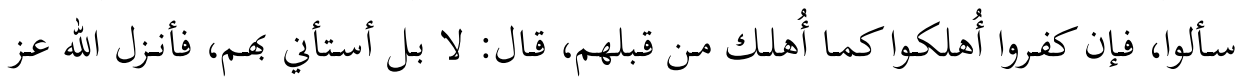

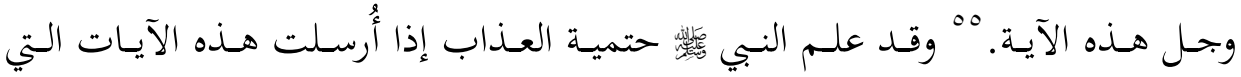

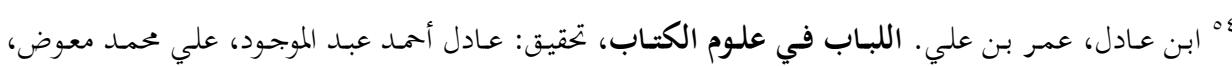

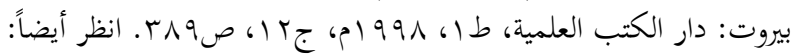

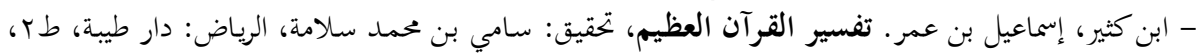

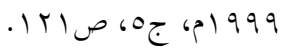

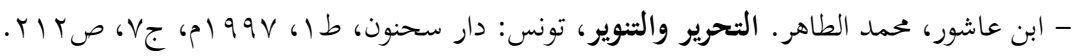

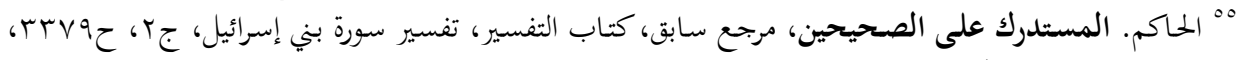

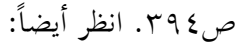

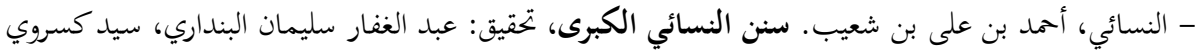

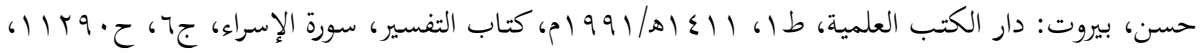




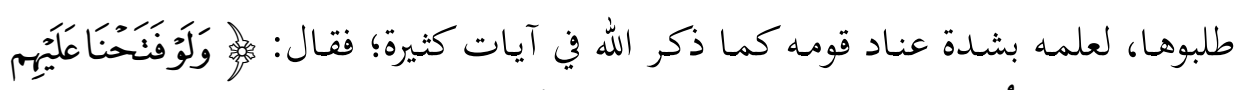

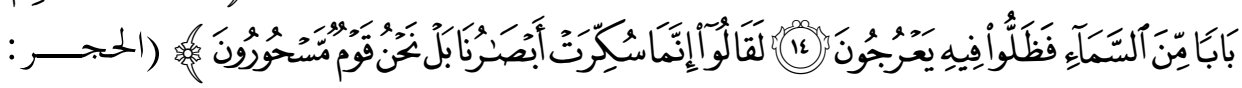

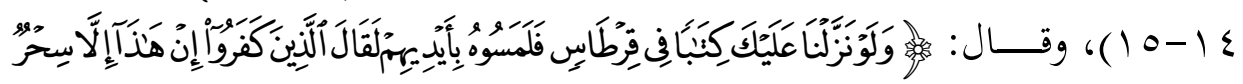

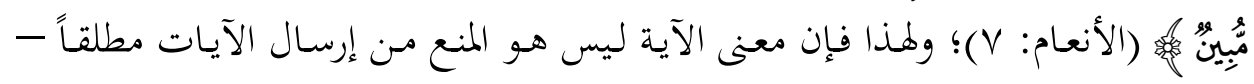
كما فهم الجابري- وإنما المنع من إرسال الآيات التي طلبوها، وهي التي ذكرت في الآية والحديث، وإلا فقد ذكر الله معجزات عظيمة أخرى كما سبق، ولهذا يقول ابن كثير عن معنى هـهـ الآيـة: "إن سـنتي في خلقي أني إذا آتيتههم مـا سـألوا فـإن آمنـوا وإلا عـاجلتهم بالعقوبة. "آه وبهذا يكون معنى الآية: وما منعنـا أن نرسل بالآيات المطلوبة إلا أن الأولين قد كذبوا بالآيات التي طلبوها فأهلكوا كما اقتضت سنة الله تعالى في خلقه.

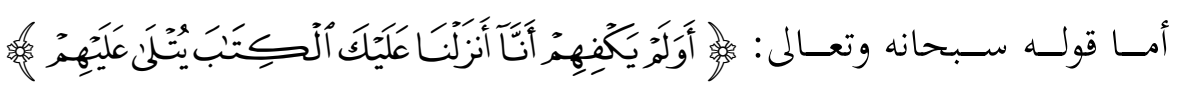

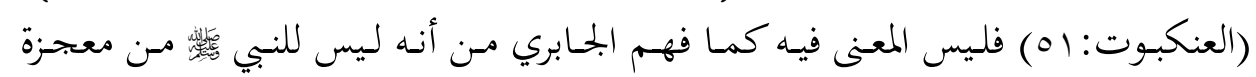

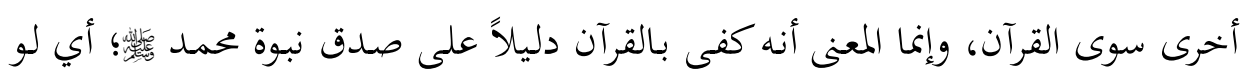
لم يكن له إلا القرآن لكفاه وحده، بالرغم من أن له معجزات أخرى غيره، ولو هُمْ تأملوا هذا القرآن لكفاهم عن طلب أي آية أو علامهة أخرى؛ إذ إنه ظاهر التفرّة، بيّن التميز، دالّ على أنه من عند الله. يقول ابن عادل: "(أولم يكفهم) عبارة تنبي عن كون القرآن آية

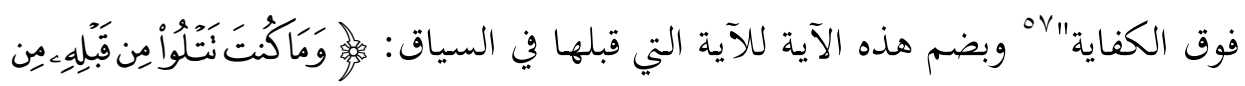

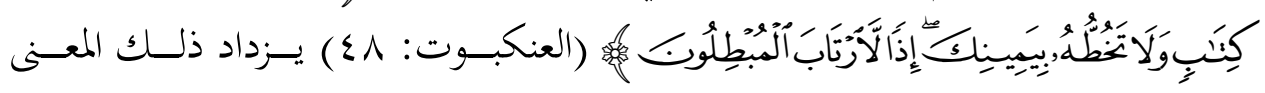
وضوحاً أيضاً، فيكون: أولم يكفهـم إنزال هذا القرآن الناطق بـالحق والنبي المنزل إليه أمي لا يقرأ ولا يكتب. ولهذا يقول ابن كثير: "وومعنى ذلك: أولم يكفهم آية دالة على صدقلك إنزالنا القـرآن عليك وأنـت أميك" "هـ وفي قوله: (يتلى عليهم) إشـارة إلى بقـاء هـا القرآن (المعجـزة اللحالـدة)، وهـو غـير المعجـزات الحسـية؛ إذ إن المعجـزات الحسـية تنقـرض بمـوت

- ابن حنبل، أحمد. مسند الإمام أحمد بن حنبل. القاهرة: مؤسسة قرطبة، د.ت، مسند بني هاشم، مسند عبد

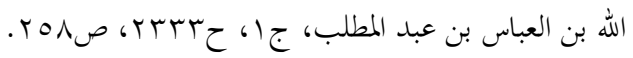

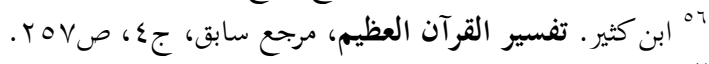

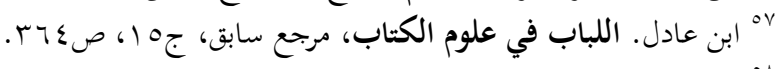

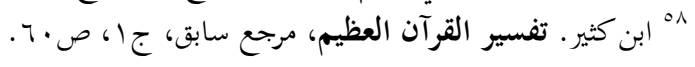




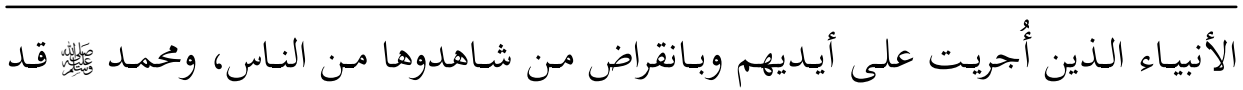

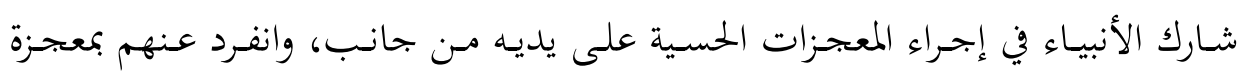

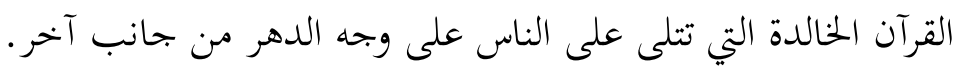

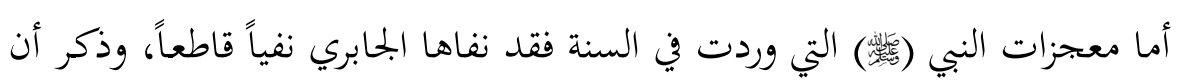

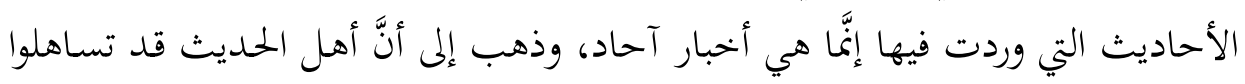

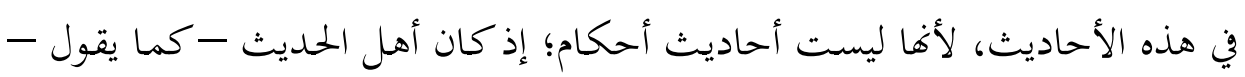

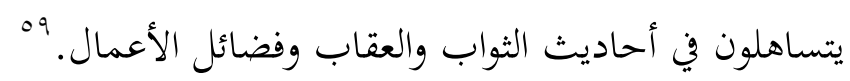

وصحيح أنَّ الأحاديث التي وردت فيها هذه المعجزات ليست أحاديث أحكام،

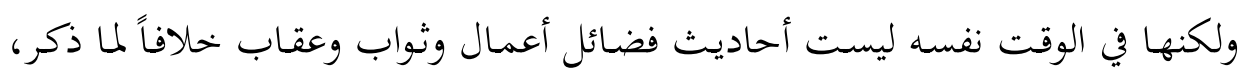
وإنما تتعلّق بإبتبات النبوة والدين نفسه.

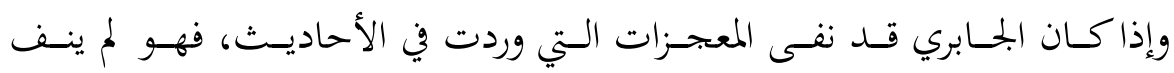

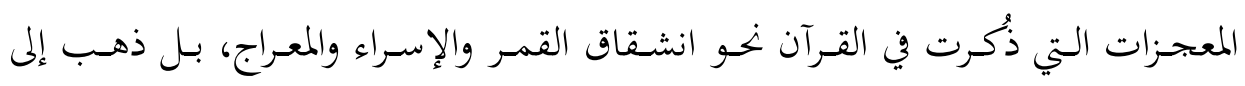
تأويلها حتى يخرجها عن إطار المعجزة؛ وتفصيل ذلك آلك كالآتي:

\section{1. - انشقاق القمر:}

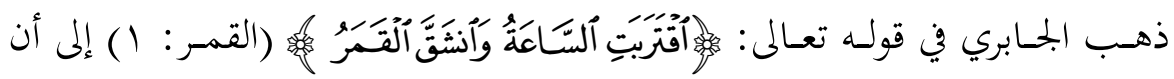

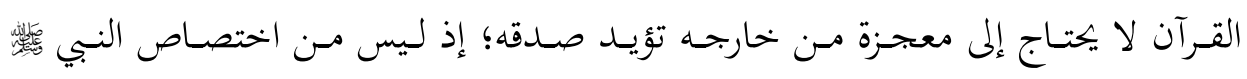

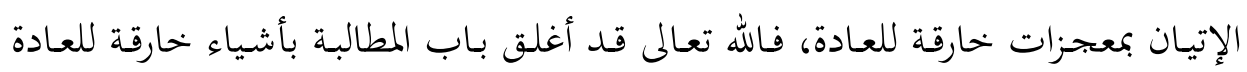

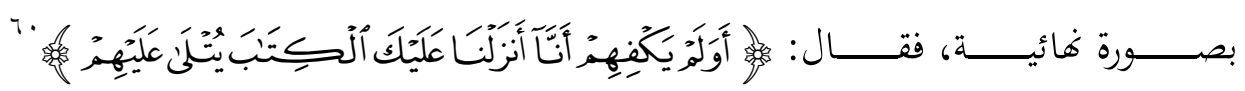

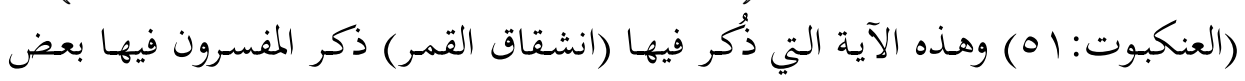

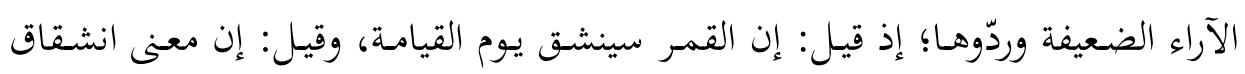

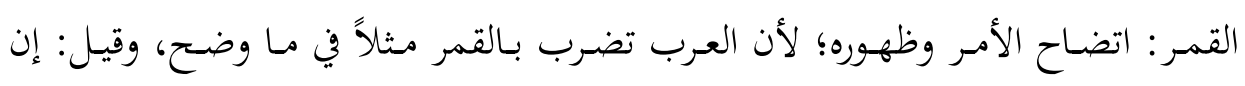

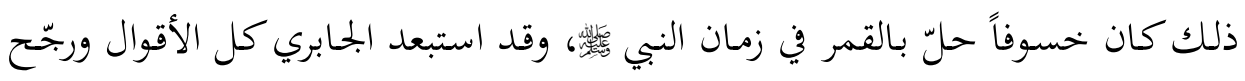

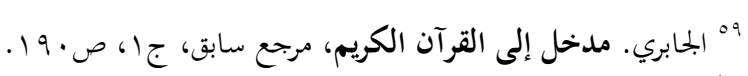

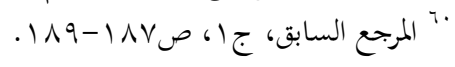


كون الذي حلٌ بالقمر "خسوفاً"، وظاهرة طبيعية عادية. 'اج وإذاكان انشقاق القمر عند الجـابري خسوفاً طبيعياً فقـد ذهـب حسـ حنفي إلى أن اقتران بعض المعجزات بـدعوات الأنبياء من قبيل الاتفاق وبمحض المصادفات. بات

ولكن أكثر العلمـاء والمفسـرين أكسّدوا على أن القمـر قـد انشـق انشقاقاً حقيقيـاً في

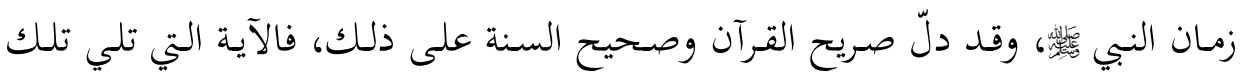
الآيـة التي تتنـاول الانشقاق مباشـرة تؤكد أن الكافرين قد رأوا هـذه الحادثة رأي العـين ولم

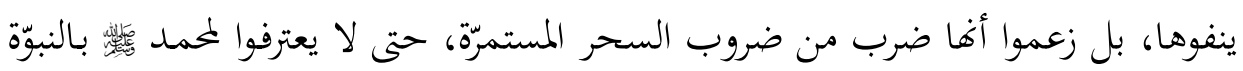

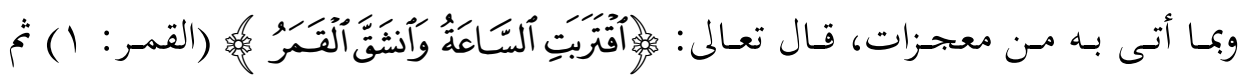

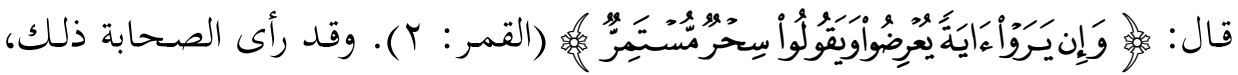

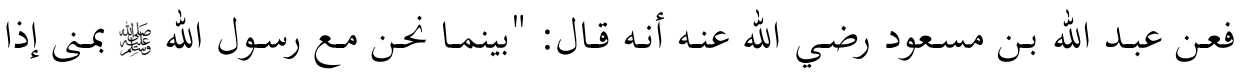

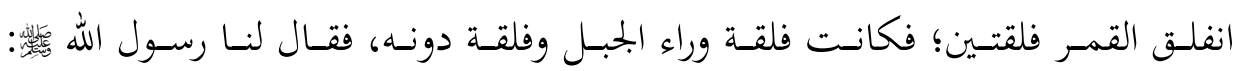
أشهـوا،" آج ويقـول ابن كثير: "قد اتفق العلماء مـع بقيـة الأئمـة على أن انشقاق القمـر

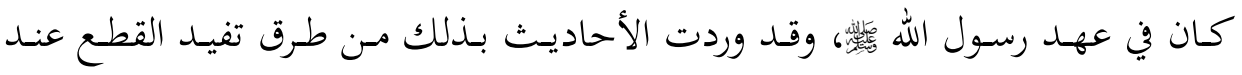

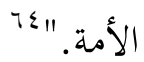

وقــد مـال الجحـابري إلى رأي ضـعيف كمـا سـبق؛ إذ ذهـب إلى أن معـنى "انشـقاق القمر "ب أي خسوفه، وقد استدلّ الجابري بقول أورده الإمام ابن عاشور وهو مرور جسسم

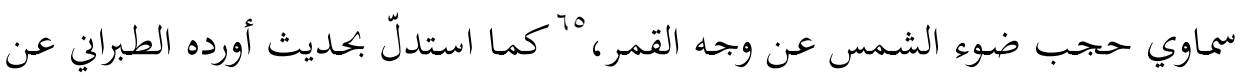

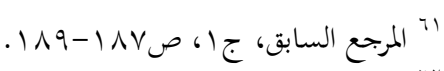

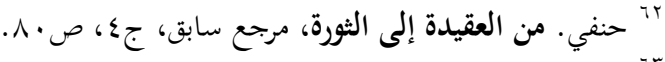

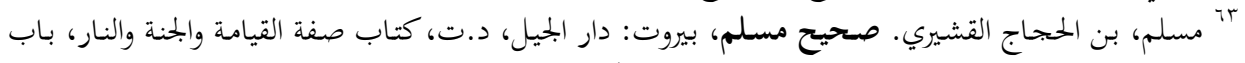

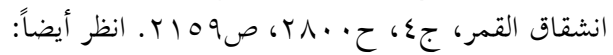

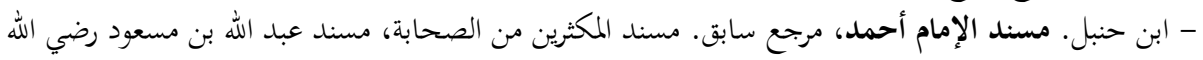

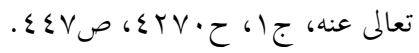

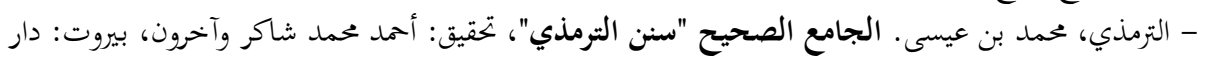

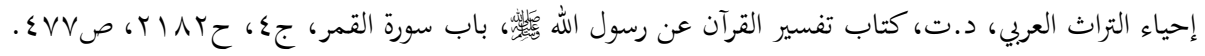

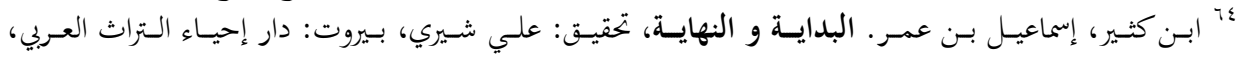




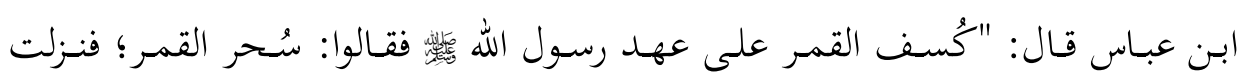

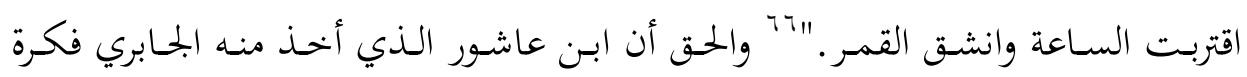

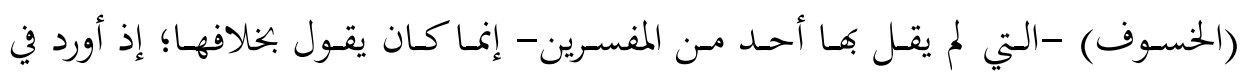

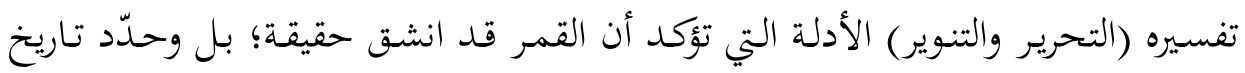

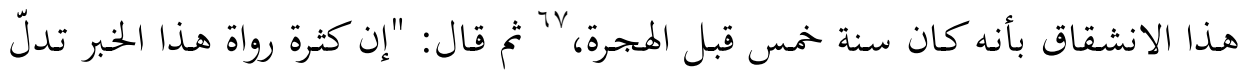

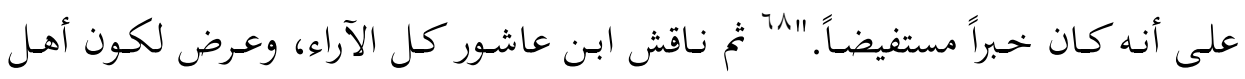

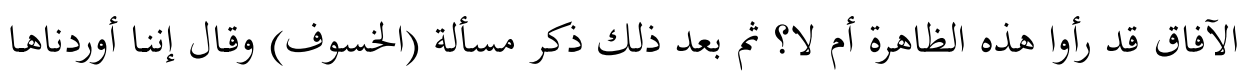

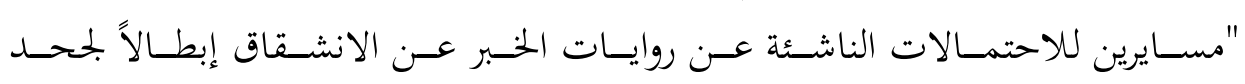
الملحدين.

والحق أن أهل الآفاق قد رأوا هذه الظاهرة، فبعد هـا الانشقاق قال الكفار: لئن

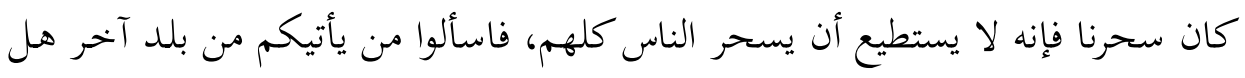

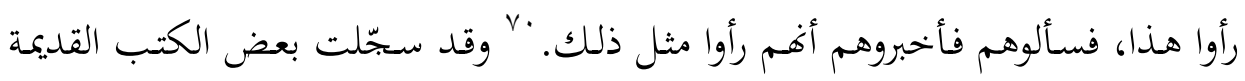

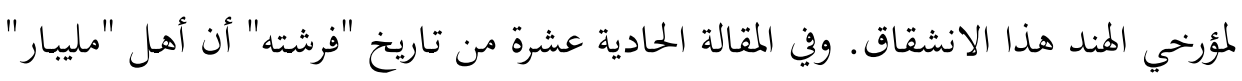

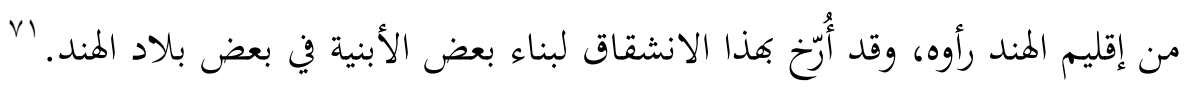
أمـا حديث الطبراني فلم يهتم بـه المفسرون؛ لأن الأدلة الثابتة بخلافه، وإنما أورده

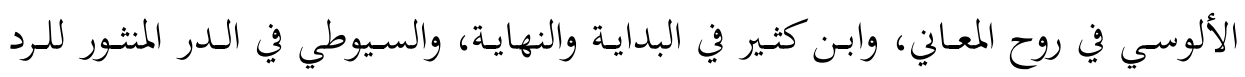

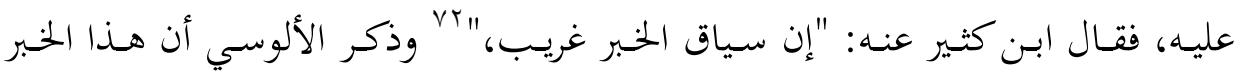

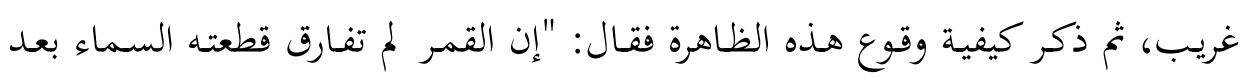

"1 الطبراني، سليمان بن أممد. المعجم الكبير، تحقيق: ممدي بن عبد الجيد السلفي، المدينة المنورة: مكتبة العلوم

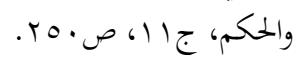

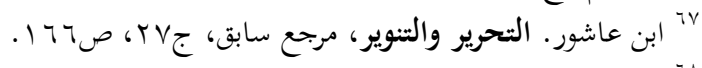

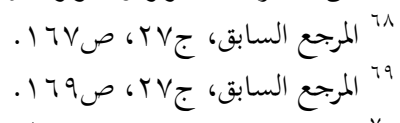

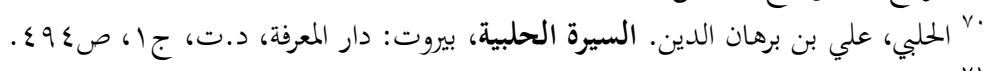

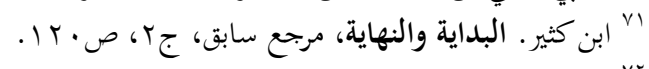

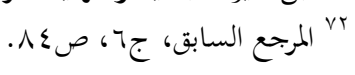


انشقاقه بل بقيتا متباعدتين تباعداً ما لحظه، ثم اتصلتا.." "V وهذا الوصف ينفي أن تكون إحلدى فلقتي القمدر قد اختفـت، سواء كان ذلك بخسوف أو غيره، وقد جاء في القرآن والسنة أن الانشقاق قد حدث فعلاً، وقد أكّد العلم الحديث ذلك.

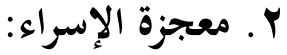

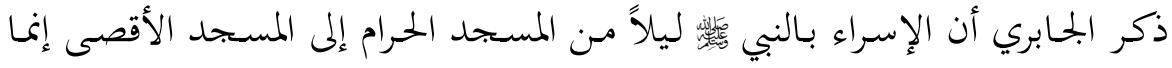

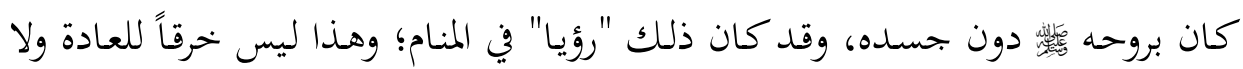

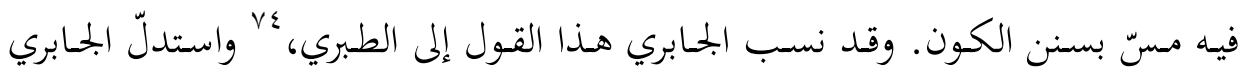

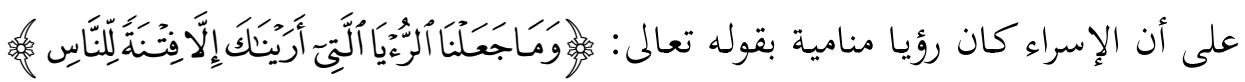

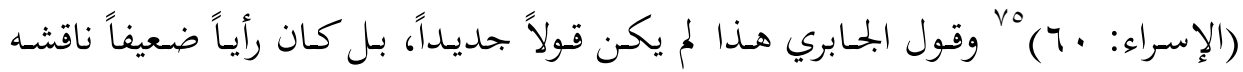
العلمـاء وأبطلـوه، وقـد عقـد القاضي عيـاض فصـلاً في كتابـه (الثـفا) للـرد على مـن قـال بذلك.

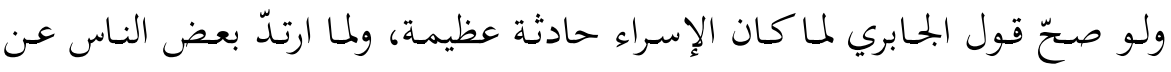
الإسلام وافتتنوا، ولما سُمي الصديق صديقاً، ولهذا يقول القرطبي: "ولو كان مناماً لما كانت

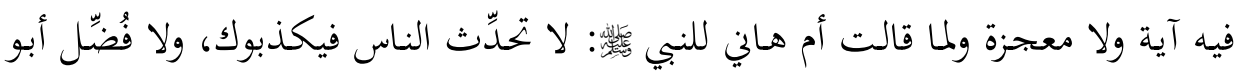
بكر بالتصديق، ولا أمكن قريش التشنيع والتكذيب، وقد كذّبته قريش فيما أخبر به حتى

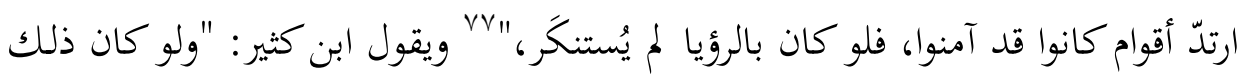

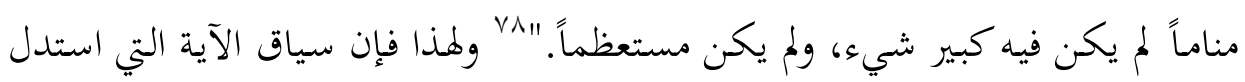
بها الجابري نفسها يكذّب ما ذهب

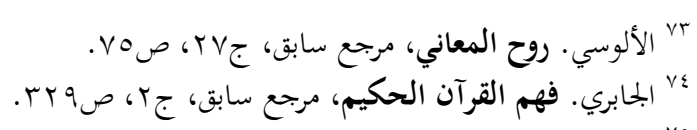

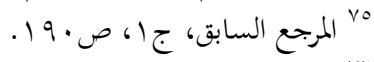

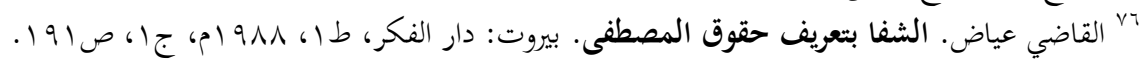

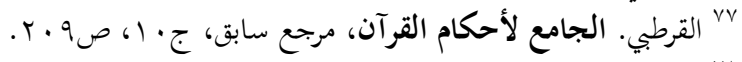

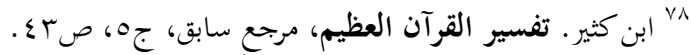

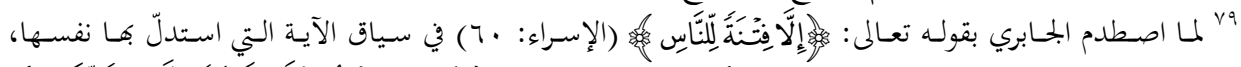

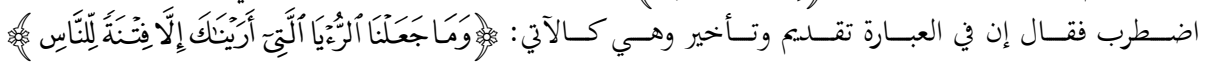




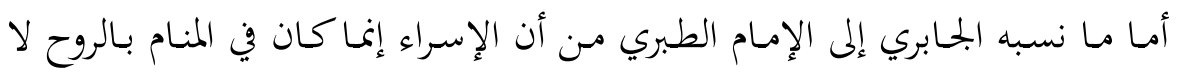

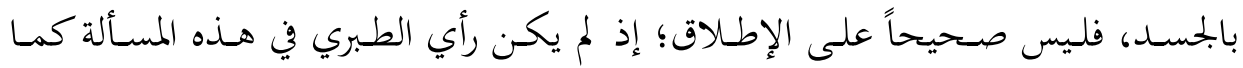

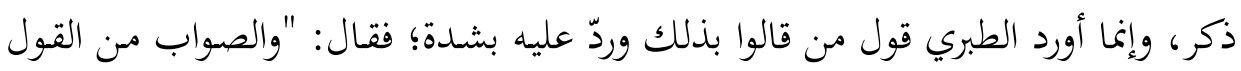

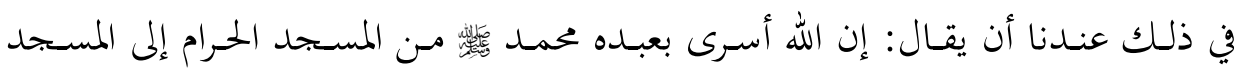

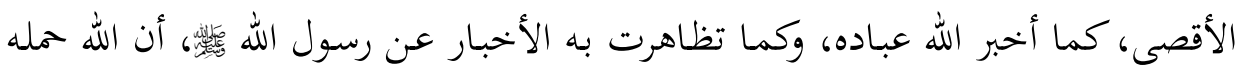

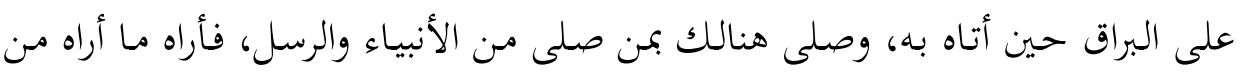

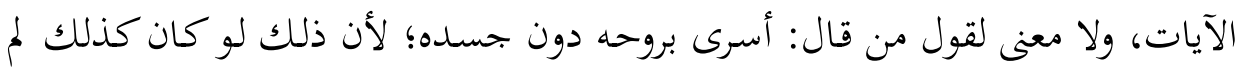

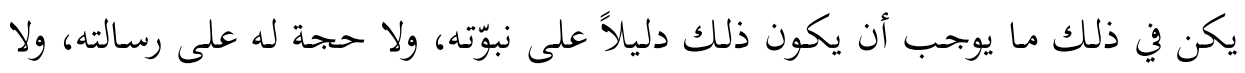

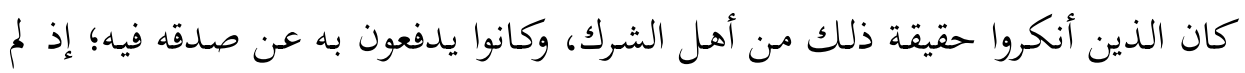

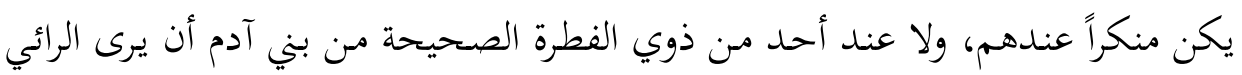

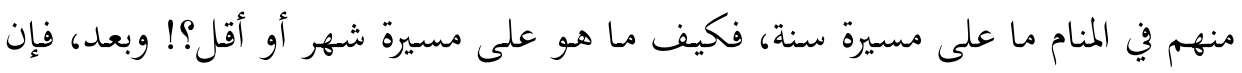

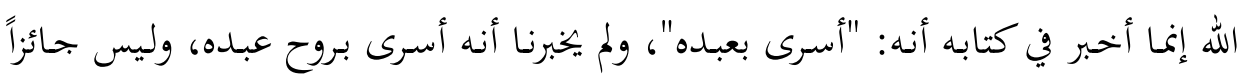

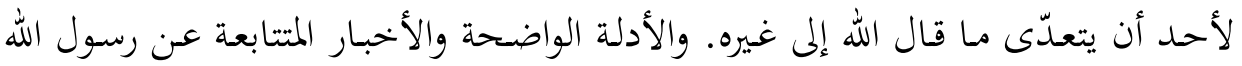

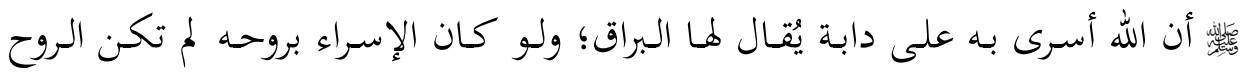

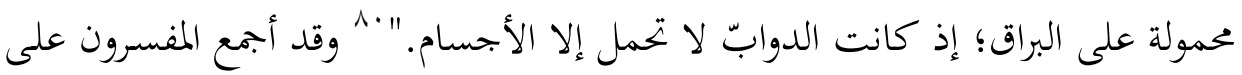

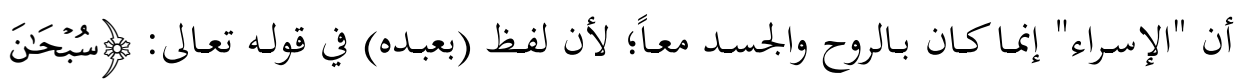

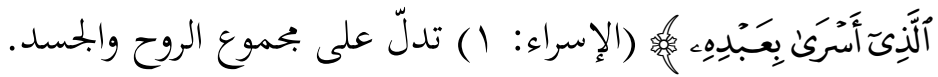

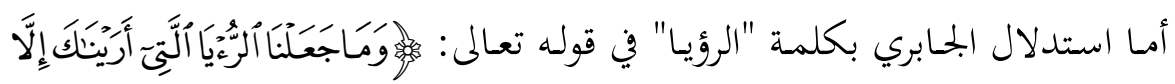

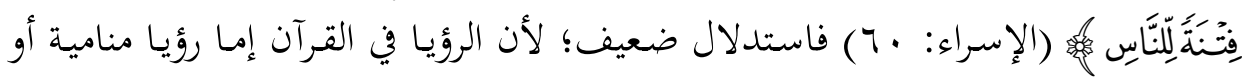

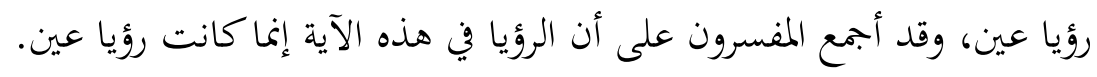

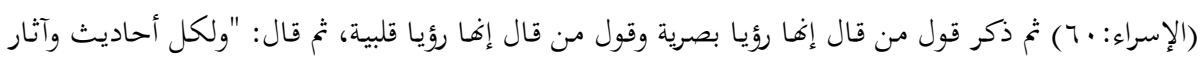

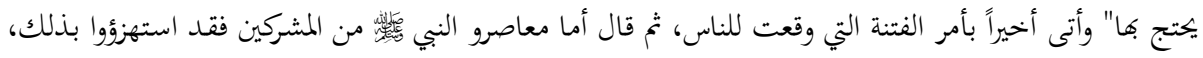

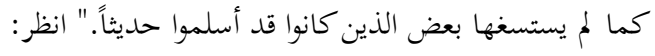

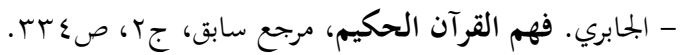

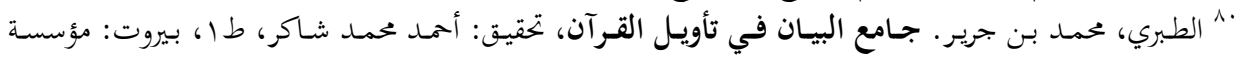

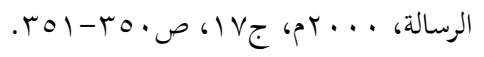




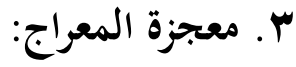

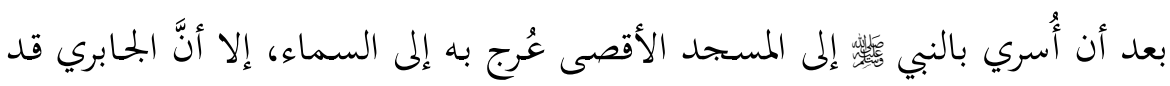

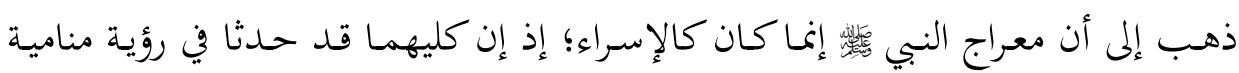

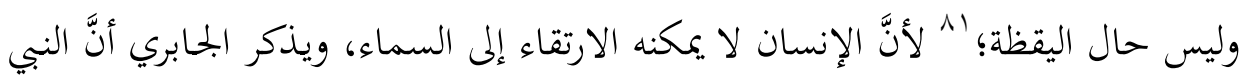

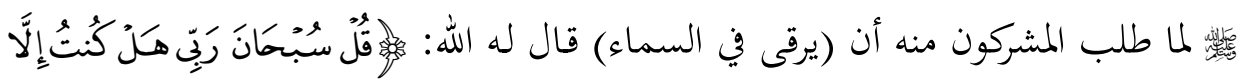

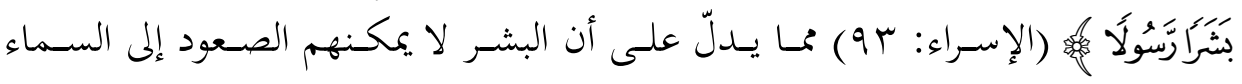
إطلاقاً.

لكن استشهاد الجابري بالآية فيه نظر؛ إذ إن المشركين في السياق نفسه قد قالوا:

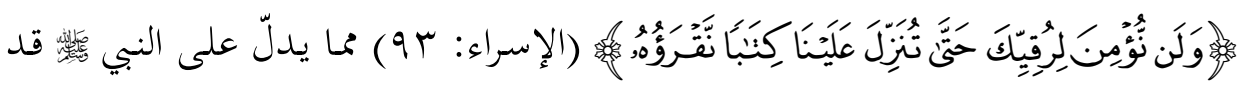

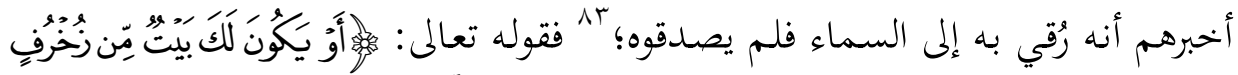

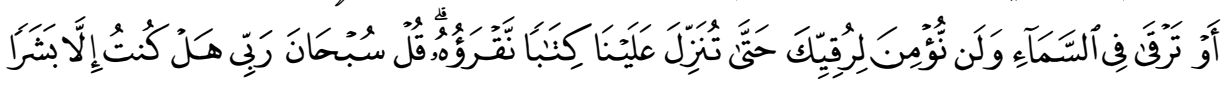

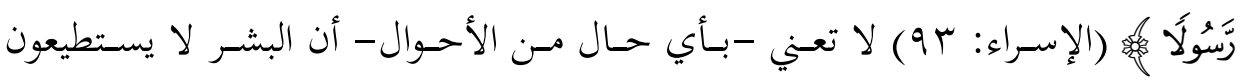

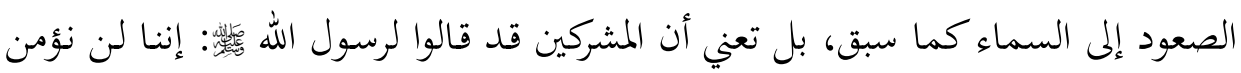

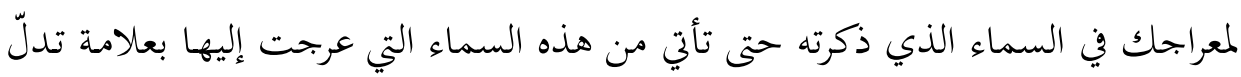

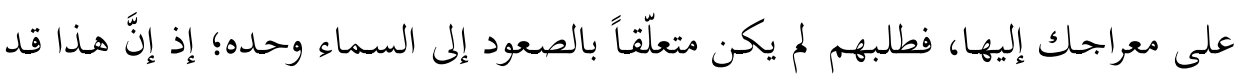

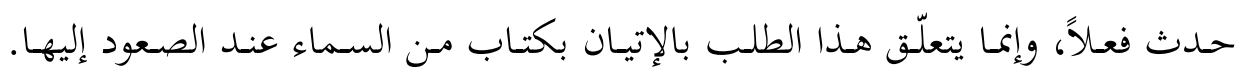

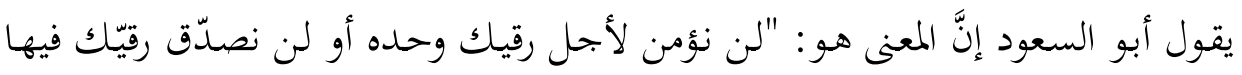

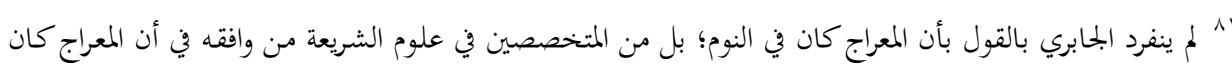

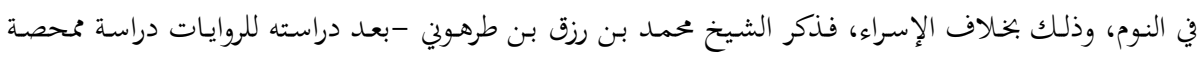

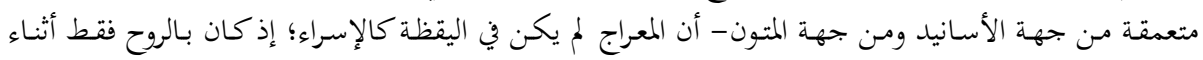

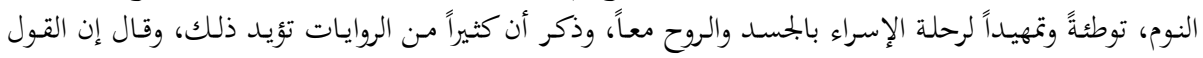

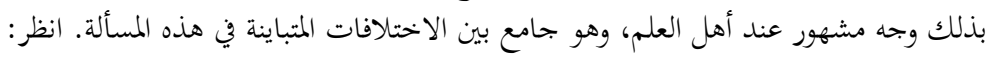

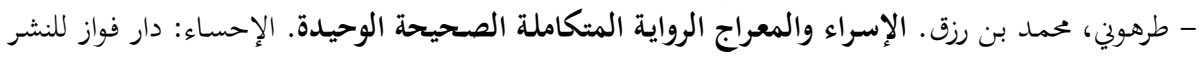

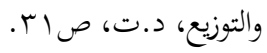

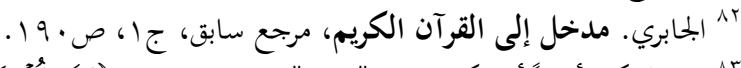

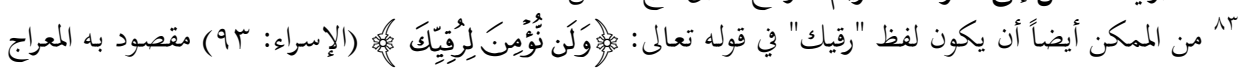
الذي طلبوه. 


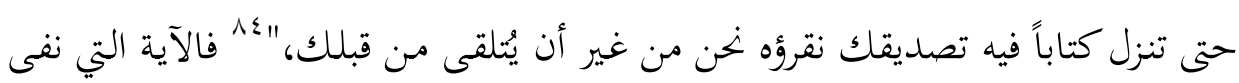

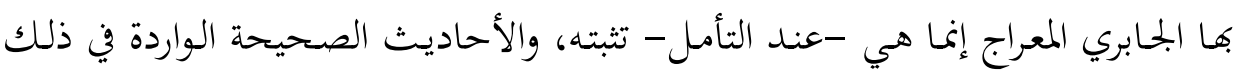

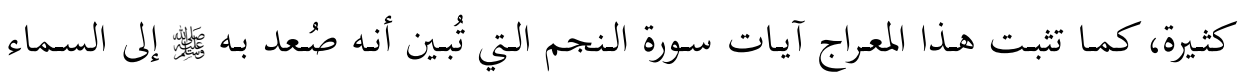

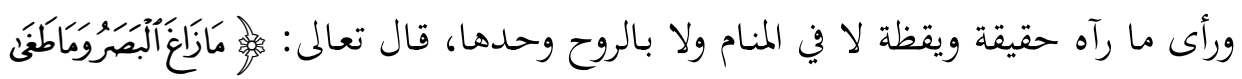

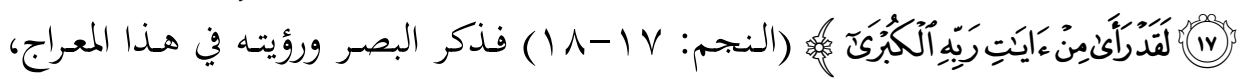

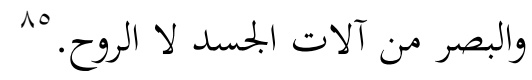

\section{خاتمة:}

إن النتائج الصحيحة المقبولة -في أي بحث من البحوث العلمية- إنما هي مشروطة

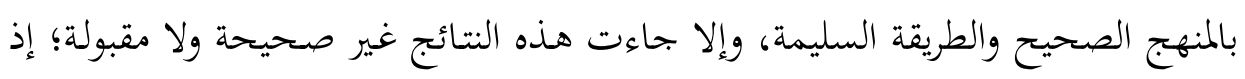

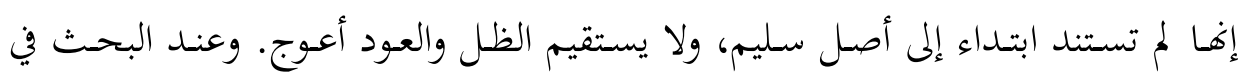

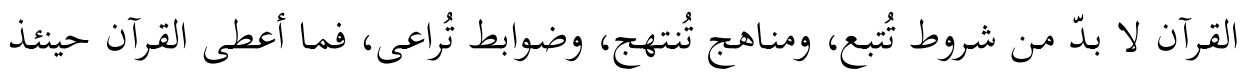

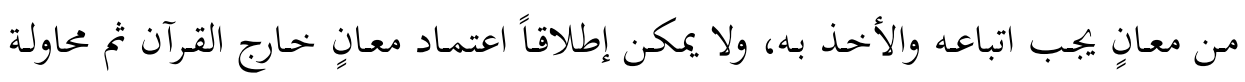

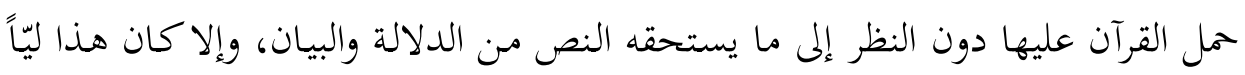

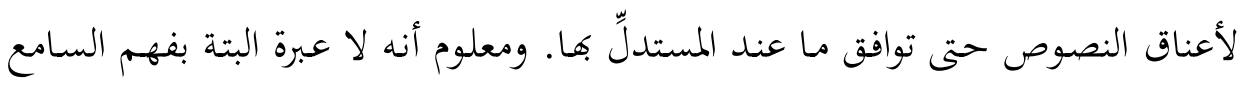

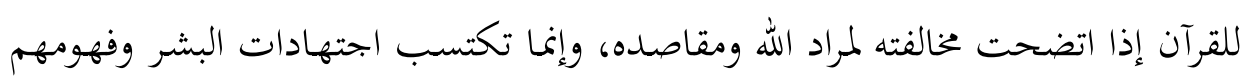

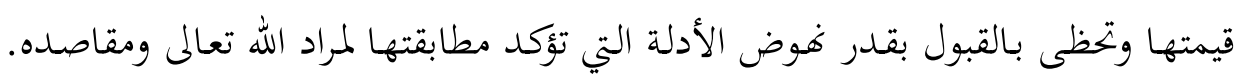

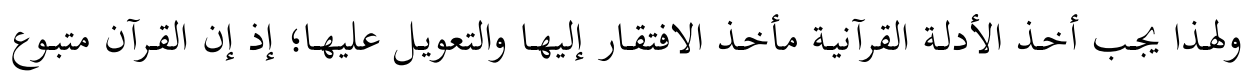

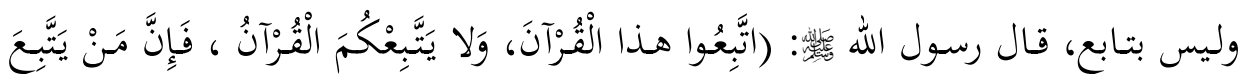

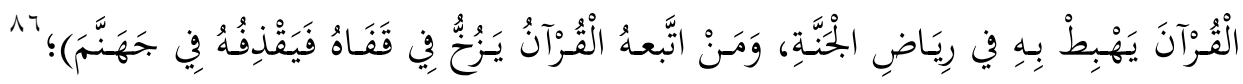

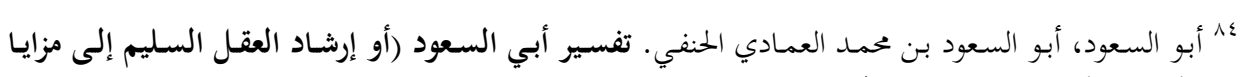

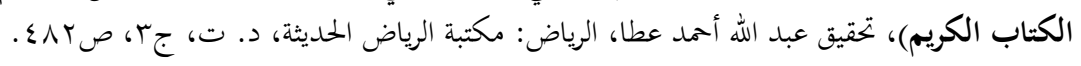

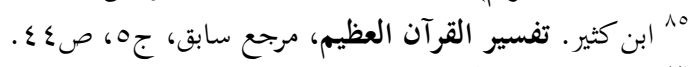

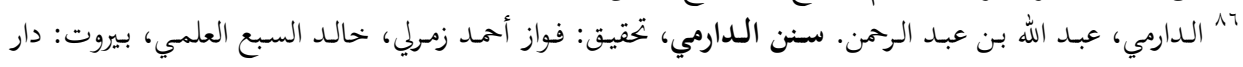

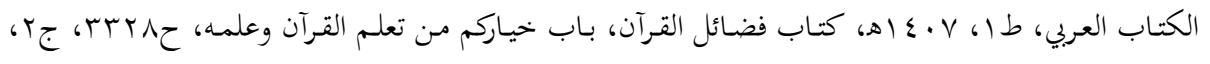




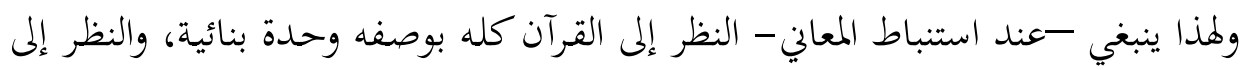

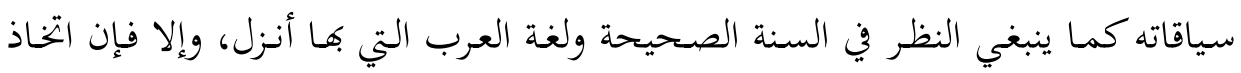

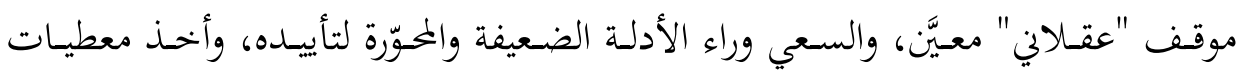

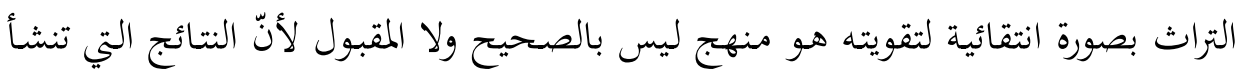

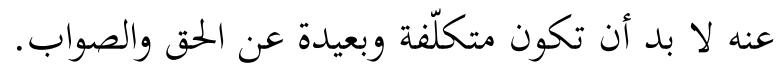
وإذا كان أصحاب القراءات الحداثية قد اتخذوا "العقلانية" مرتكزاً، والأسباب المادية

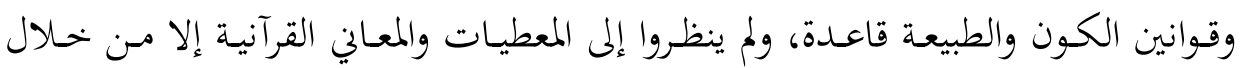

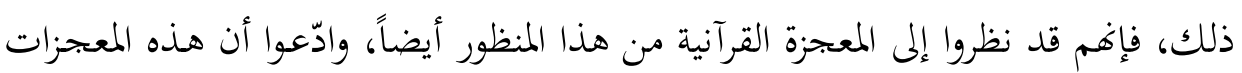

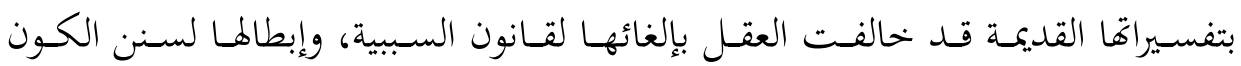

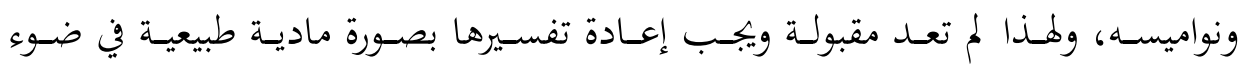

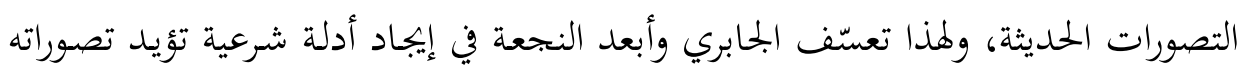

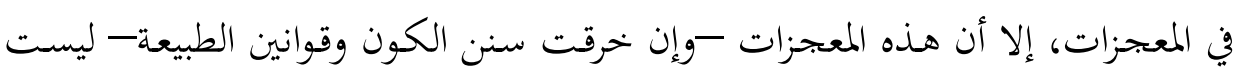

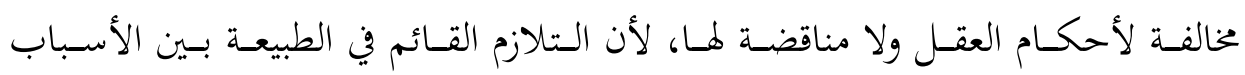

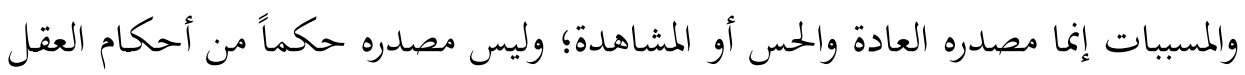

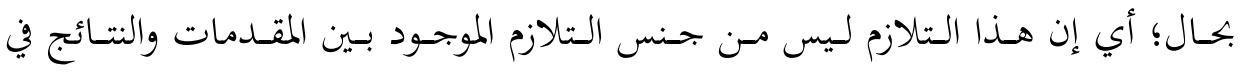

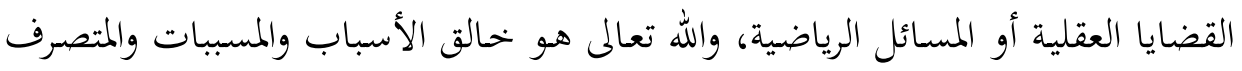

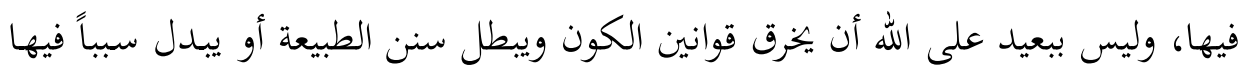
بسبب آخر؛ ليكون ذلك دليلاً على النبوة. 